\title{
Depolymerization of Technical Lignins in Supercritical Ethanol: Effects of Lignin Structure and Catalyst
}

Erika Bartolomei ${ }^{a}$, Yann Le Brech ${ }^{a}$, Roger Gadioub ${ }^{b}$ Frédérique Bertaud ${ }^{c}$, Sébastien Leclerc ${ }^{\mathrm{a}}$, Loïc Vidal ${ }^{\mathrm{b}}$, Jean-Marc Le Meins ${ }^{b}$, Anthony Dufour ${ }^{*}$

*corresponding author: anthony.dufour@univ-lorraine.fr

a Université de Lorraine, CNRS, Fédération J. Villermaux, ENSIC, 1 rue Grandville 54000 Nancy, France

b Université de Haute Alsace, CNRS, IS2M, 15 Rue Jean Starcky, 68057 Mulhouse, France

c Centre technique du Papier, 341 Rue de la Papeterie, 38400 Saint-Martin-d'Hères, France

\section{Supporting Information}

For publication

Outline of this supporting information

1. Literature overview on technical lignins depolymerization in alcohols .............................................2

2. Production of a Kraft lignin (K3) from an industrial black liquor ..................................................... 3

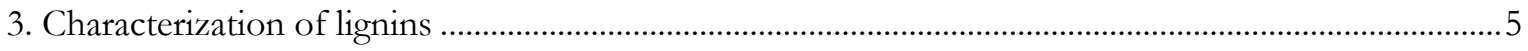

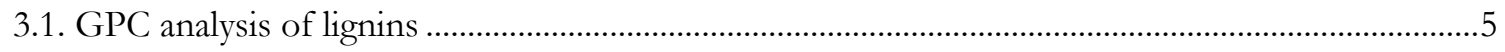

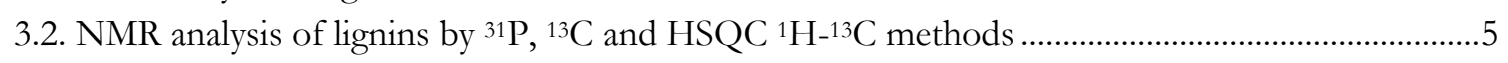

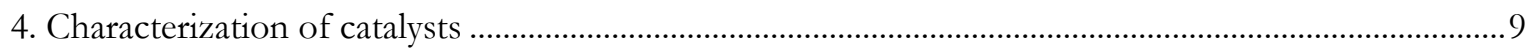

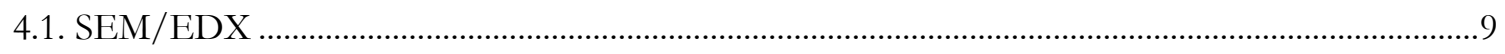

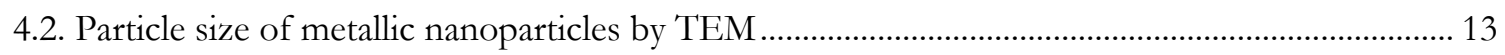

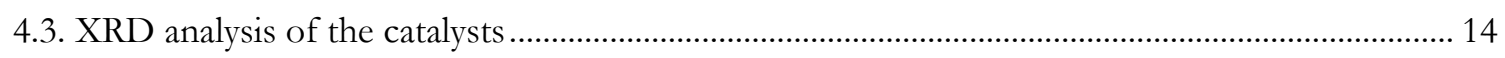

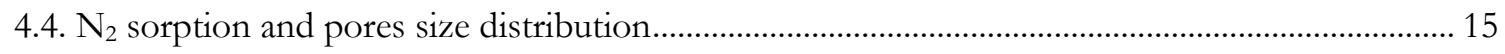

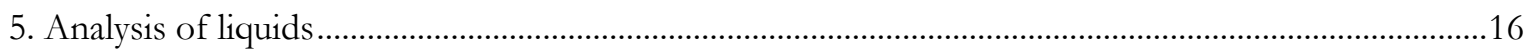

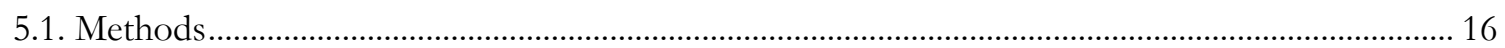

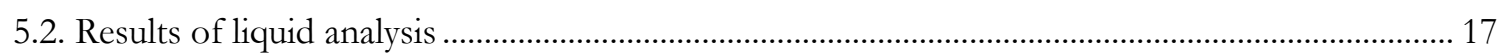

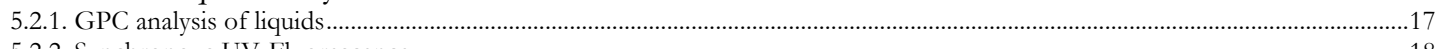

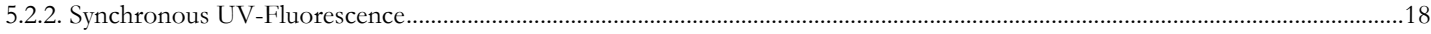

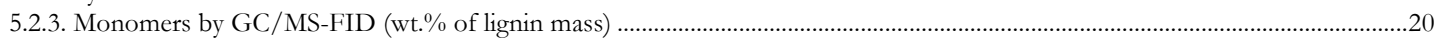

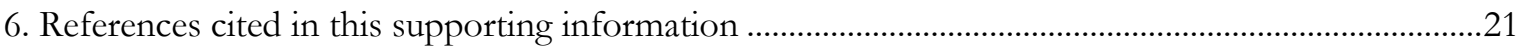




\section{Literature overview on technical lignins depolymerization in alcohols}

Table S1. Overview (not exhaustive) of technical lignins catalytic depolymerization in alcohols

\begin{tabular}{|c|c|c|c|c|c|c|}
\hline Reference & Lignin & Catalyst & Solvent & T-P- $\tau$ & Characterization & Main results \\
\hline $\begin{array}{l}\text { Jongerius, } \\
2013^{1}\end{array}$ & $\begin{array}{l}\text { Organosol, Kraft } \\
\text { \& bagasse lignin }\end{array}$ & $\begin{array}{l}\mathrm{Pt} / \mathrm{Al}_{2} \mathrm{O}_{3} \text {, then } \\
\mathrm{CoMo} / \mathrm{Al}_{2} \mathrm{O}_{3} \& \\
\mathrm{Mo}_{2} \mathrm{C} / \mathrm{CNF}\end{array}$ & $\begin{array}{l}\text { Ethanol- } \\
\text { water }\end{array}$ & $\begin{array}{l}2 \text { stages: } \\
225^{\circ} \mathrm{C}- \\
58 \mathrm{Bar}, 2 \mathrm{~h} \text {, } \\
\text { then } 350^{\circ} \mathrm{C}- \\
55 \mathrm{Bar} \mathrm{H}_{2}- \\
4 \mathrm{~h} \text { for } \mathrm{HDO} \\
\text { of oils }\end{array}$ & GC \& GPC & $9 \mathrm{wt} . \%$ monomer \\
\hline $\begin{array}{l}\text { Huang, } \\
2014^{2}\end{array}$ & Protobind P1000 & $\begin{array}{l}\text { CuMgAlOx, } \\
\text { MgAlOx, } \\
\text { PtMgAlOx, } \\
\text { NiMgAlOx }\end{array}$ & $\mathrm{EtOH}$ & $300^{\circ} \mathrm{C} ; 0-8 \mathrm{~h}$ & $\begin{array}{l}\text { GC-MS, HSQC } \\
\text { NMR, GPC }\end{array}$ & $\begin{array}{l}\text { monomers } 4-23 \\
\% \text { wt, char } 0-40 \% w t\end{array}$ \\
\hline $\begin{array}{l}\text { Huang, } \\
2015^{3}\end{array}$ & $\begin{array}{l}\text { Protobind } \\
\text { P1000, Alcell, } \\
\text { Kraft } \\
\end{array}$ & $\mathrm{Cu} 20 \mathrm{MgAl}$ & $\begin{array}{l}\mathrm{EtOH} \\
\mathrm{MeOH}\end{array}$ & $\begin{array}{l}300-380^{\circ} \mathrm{C} \\
4-8 \mathrm{~h}\end{array}$ & $\begin{array}{l}\text { GC-MS, HSQC } \\
\text { NMR, GPC }\end{array}$ & $\begin{array}{l}\text { up to } 60 \% \text { wt } \\
\text { monomers (not all } \\
\text { aromatic) at } 380^{\circ} \mathrm{C}\end{array}$ \\
\hline Zhou, $2018^{4}$ & Alkali lignin & $\begin{array}{l}\mathrm{Ru} / \mathrm{C}, \mathrm{Ni} / \mathrm{Zsm}- \\
5, \mathrm{CuNiAl} \\
\text { hydrotalcite }\end{array}$ & $\begin{array}{l}\text { EtOH+ } \\
\text { Phenol }\end{array}$ & $\begin{array}{l}230-310^{\circ} \mathrm{C} \\
1-10 \mathrm{~h}\end{array}$ & $\begin{array}{l}\text { CHONS, GPC, } \\
\text { BET, XPS, ICP- } \\
\text { AES, TGA, XRD, } \\
\text { NH3/CO2-TPD }\end{array}$ & $82 \%$ wt bio-oil \\
\hline $\begin{array}{l}\text { Limarta, } \\
2018^{5}\end{array}$ & $\begin{array}{l}\text { Kraft; } \\
\text { Organosolv }\end{array}$ & $\mathrm{Ru} / \mathrm{C} 10 \% \mathrm{wt}$ & $\mathrm{EtOH}$ & $350^{\circ} \mathrm{C} ; 4 \mathrm{~h}$ & $\begin{array}{l}\text { GC-MS-FID; } \\
\text { GPC; CHONS }\end{array}$ & $\begin{array}{l}88 \% \text { wt bio-oil; } \\
7.3 \% \text { wt monomers. } \\
\text { Synergy } \\
\mathrm{MgO} / \mathrm{ZrO} 2+\mathrm{Ru} / \mathrm{C}\end{array}$ \\
\hline $\mathrm{Kim}, 2015^{6}$ & Protobind 1000 & $\begin{array}{l}\mathrm{Pt} / \mathrm{C}, \mathrm{Ru} / \mathrm{C} \\
\mathrm{Ni} / \mathrm{C} 5 \% \mathrm{wt}\end{array}$ & $\mathrm{EtOH}$ & $\begin{array}{l}350^{\circ} \mathrm{C} \\
40 \mathrm{~min}\end{array}$ & $\begin{array}{l}\text { GC-MS, HSQC } \\
\text { NMR, GPC, } \\
\text { CHON }\end{array}$ & $\begin{array}{l}10 \% \text { wt monomers } \\
\text { for all the catalysts in } \\
\text { EtOH, less char with } \\
\mathrm{Pt} / \mathrm{C}\end{array}$ \\
\hline Yang, $2016^{7}$ & Kraft & $\begin{array}{l}\mathrm{Pt} / \mathrm{C}, \mathrm{Ru} / \mathrm{C} \\
5 \% \mathrm{wt}\end{array}$ & $\begin{array}{l}\text { Isopropa } \\
\text { nol }\end{array}$ & $\begin{array}{l}270-350^{\circ} \mathrm{C} ; \\
1-5 \mathrm{~h}\end{array}$ & $\begin{array}{l}\text { GC-MS, HSQC } \\
\text { NMR, GPC, HHV }\end{array}$ & $72-100 \%$ wt bio-oil \\
\hline Kong, $2019^{8}$ & Kraft & $\begin{array}{l}\mathrm{NiCu} \text { over } \\
\text { various zeolites }\end{array}$ & $\begin{array}{l}\text { Isopropa } \\
\text { nol, } \\
\text { compare } \\
\text { d with } \\
\text { other } \\
\text { alcohols }\end{array}$ & $\begin{array}{l}330^{\circ} \mathrm{C}, 3 \mathrm{~h} \\
\text { (best } \\
\text { conditions) }\end{array}$ & $\begin{array}{l}\text { GC/MS, GPV, } \\
\text { elemental analysis } \\
\text { Cata: XRD, SEM, } \\
\text { ICP, TGA }\end{array}$ & $\begin{array}{l}\text { Less aromatics with } \\
\text { catalysts than } \\
\text { without catal. More } \\
\text { directed to } \\
\text { cycloalkanes } \\
\text { production } \\
\text { (important } \\
\text { hydrogenation of the } \\
\text { aromatic rings) }\end{array}$ \\
\hline $\begin{array}{l}\text { Xiao et al. } \\
2020^{9}\end{array}$ & $\begin{array}{l}\text { Various lignins } \\
\text { from Eucalyptus }\end{array}$ & $\mathrm{Pd} / \mathrm{C}$ & $\mathrm{MeOH}$ & $180^{\circ} \mathrm{C}, 4 \mathrm{~h}$ & $\begin{array}{l}\text { GC-MS, HSQC } \\
\text { NMR, GPC }\end{array}$ & $\begin{array}{l}\text { Relations between } \beta \text { - } \\
\text { O-4 and phenol OH } \\
\text { contents and } \\
\text { monomers yields }\end{array}$ \\
\hline $\begin{array}{l}\text { Cheng et al. } \\
2020^{10}\end{array}$ & $\begin{array}{l}\text { Organosolv } \\
\text { lignin, Kraft, etc. }\end{array}$ & $\mathrm{Ni}-\mathrm{Cu} / \mathrm{C}$ & $\begin{array}{l}\text { IPrOH/ } \\
\text { EtOH }\end{array}$ & $270^{\circ} \mathrm{C}, 4 \mathrm{~h}$ & $\begin{array}{l}\text { GC/MS, NMR, } \\
\text { GPC } \\
\text { Catal: XRD, XPS, } \\
\text { SEM, sorption, } \\
\text { ICP }\end{array}$ & $\begin{array}{l}\text { Synergy between } \\
\text { ethanol/propanol } \\
23 \% \text { phenols for } \\
\text { Kraft }\end{array}$ \\
\hline $\begin{array}{l}\text { Limarta et } \\
\text { al. } 2020^{11}\end{array}$ & $\begin{array}{l}\text { Organosolv } \\
\text { lignin }\end{array}$ & $\begin{array}{l}\mathrm{Ru} / \mathrm{C}+\mathrm{MgO}- \\
\mathrm{ZrO}_{2}\end{array}$ & $\mathrm{EtOH}$ & $350^{\circ} \mathrm{C}, 4 \mathrm{~h}$ & $\begin{array}{l}\text { GC/MS, HSQC, } \\
\text { XRD, acid/base } \\
\text { properties of } \\
\text { catalyst }\end{array}$ & $\begin{array}{l}\text { Synergy between } \\
\mathrm{Ru} / \mathrm{C} \\
\text { (depolymerization) } \\
\text { and } \mathrm{MgO} / \mathrm{ZrO}_{2} \\
\text { (stabilization). } 31 \text { wt. } \\
\text { phenolic monomers }\end{array}$ \\
\hline
\end{tabular}




\section{Production of a Kraft lignin (K3) from an industrial black liquor}

The K3 Kraft lignin was prepared at semi-pilot scale from a black liquor (BL) sampled in an industrial Kraft mill (Facture, Smurfit Kappa, France). This mill operates mainly with Pine wood. The BL entering the last concentration step in the Kraft mill was selected as the most suitable BL for lignin preparation because it is sufficiently concentrated in organic matter and not too viscous for further precipitation and stirring. $80 \mathrm{~L}$ of $\mathrm{BL}$ was sampled.

The main characteristics of the sampled black liquor are presented in table S2.

Table S 2. Main characteristics of the sampled black liquor used for K3 production

\begin{tabular}{|l|l|}
\hline $\begin{array}{l}\text { Dry matter content } \\
(\mathrm{g} / 100 \mathrm{~g} \text { of crude sample })\end{array}$ & 43.6 \\
\hline Density $20^{\circ} \mathrm{C}\left(\mathrm{g} / \mathrm{cm}^{3}\right)$ & 1.21 \\
\hline CHNS (g/100g dry & $\begin{array}{l}33.69 / 3.85 / 0.10 / \\
1.21\end{array}$ \\
sample)
\end{tabular}

Carbon quantification in the pristine $\mathrm{BL}$ by TOCmeter was compared to carbon quantification by elemental analysis (CHNS) on the dried liquor residue. Results are similar (presented in Table S3) showing that almost all the carbon determined by TOC, which is dissolved in the solution, is quantified by CHNS after drying.

Table S3. Carbon Organic (TOC) analysis compared to Elemental analysis (CHNS) of the black liquor

\begin{tabular}{|l|l|l|l|l|}
\hline $\begin{array}{l}\text { C (TOC) } \\
\text { (g/g liq) }\end{array}$ & $\begin{array}{l}\% \text { dry matter } \\
\text { in BL }\end{array}$ & $\begin{array}{l}\% \mathrm{C} \text { dry matter } \\
\text { (TOC) }\end{array}$ & $\begin{array}{l}\% \mathrm{C} \\
\text { (CHNS) }\end{array}$ & $\begin{array}{l}\text { ratio } \\
\text { TOC/CHNS }\end{array}$ \\
\hline 0.14 & 43.6 & 32.42 & 33.69 & 0.96 \\
\hline
\end{tabular}

The Kraft lignin has been precipitated from this BL following a protocol developed by the French Technical Center of Paper (CTP, Grenoble) at a semi-pilot scale to produce $\sim 2-4 \mathrm{~kg}$ dry basis lignin per batch.

The procedure presents 4 main steps as described in Figure S1. 


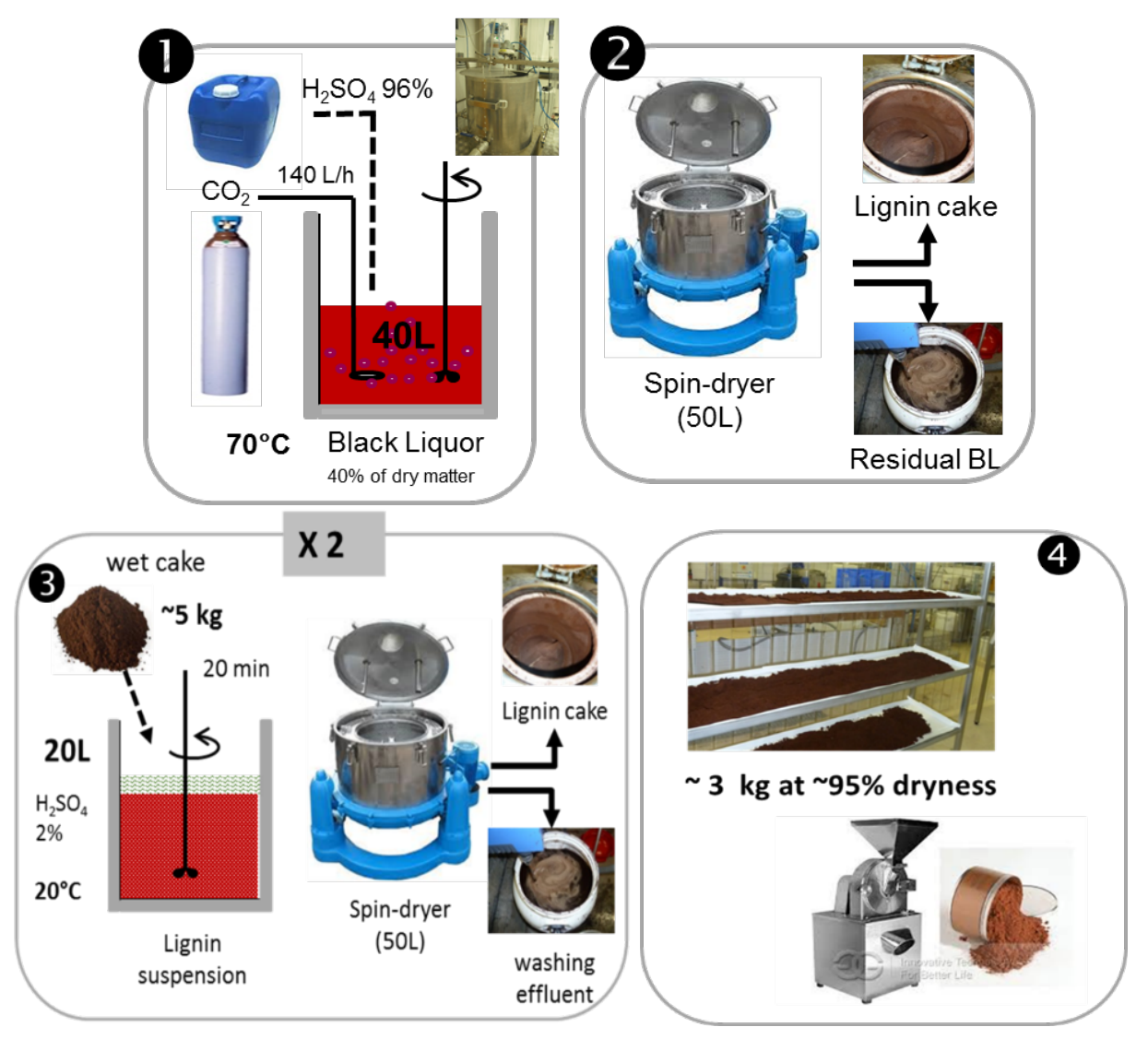

Figure S1. Scheme and protocol for the precipitation of the Kraft lignin at semi-pilot scale from an industrial Black liquor (BL) (BL:40\% dry matter, $70^{\circ} \mathrm{C}, \mathrm{pH} 9$ and acidic washings)

The main steps are the followings:

1) Neutralization of the black liquor (BL) until $\mathrm{pH} 9$ by $\mathrm{CO}_{2}$ bubbling, which leads to a lignin suspension (neutralisation at $70^{\circ} \mathrm{C} / \mathrm{Patm}$ under continuous stirring). In some cases, sulphuric acid addition could be needed to reach $\mathrm{pH} 9$ faster.

2) Lignin separation by filtration of the obtained suspension, using a spin dryer, which leads to a crude lignin cake and the residual black liquors (RBL)

3) Lignin purification by successive acidic washings of the lignin cake (two times in the standard protocol), which leads to a purified lignin cake,

4) Lignin cake drying by laying the crumbled lignin cake on rack at ambient conditions during 3-5 days, and powdering.

The $80 \mathrm{~L}$ of BL gave $7 \mathrm{~kg}$ of Kraft lignin (in 2 batches: $50 \mathrm{~L}$ and 30L). The global yield was $22.1 \mathrm{wt} . \%$ (g dry lignin powder/g of initial dry matter in the BL).

This Kraft lignin named "K3" was then characterized by the various methods as for the 3 other technical lignins. 


\section{Characterization of lignins}

\subsection{GPC analysis of lignins}

This analysis was conducted to compare the molecular weight of lignins. The authors are aware that this type of analysis does not give the true molecular weight due to different hydrodynamic volumes of polystyrenes standards and lignins for a same molecular weight ${ }^{12}$ but PS standards were used for sake of comparison with the available literature on lignin liquefaction ${ }^{13-16}$.

The main conditions of the GPC method were:

Sample preparation: lignin solution at $4 \mathrm{~g} / \mathrm{L}$ in eluent, $48 \mathrm{~h}$ of stirring, diluted before filtration $(0.22 \mu \mathrm{m})$ and injection.

Injection volume: $20 \mu \mathrm{L}$

Eluent : DMAc/ $\mathrm{LiCl}(0.5 \% \mathrm{LiCl}$ in anhydrous DMAc), $0.5 \mathrm{~mL} / \mathrm{min}$

Detector : UV $280 \mathrm{~nm}$

2 columns in series : Waters Styragel $300 \mathrm{Mm} \times 7.8 \mathrm{~mm}: 1$ [100 - $5000 \mathrm{Da}]$ and 2 [5 $000-600000 \mathrm{Da}]$; columns maintained at $60^{\circ} \mathrm{C}$,

Standards: Polystyrene $5 \mathrm{~g} / \mathrm{L}$ in eluent (8 standards between 1140 to $150000 \mathrm{~g} / \mathrm{mol}$ )

\subsection{NMR analysis of lignins by ${ }^{31} \mathrm{P},{ }^{13} \mathrm{C}$ and $\mathrm{HSQC}{ }^{1} \mathrm{H}-{ }^{13} \mathrm{C}$ methods}

Lignin samples were dried at $105^{\circ} \mathrm{C}$ overnight. Approximately $25 \mathrm{mg}$ were used for each analysis. Lignin samples were weighed in to a $5 \mathrm{ml}$ volumetric flasks. A solvent mixture of pyridine $/ \mathrm{CDCl}_{3}(1.6 / 1 \mathrm{v} / \mathrm{v})$ was prepared in a $20 \mathrm{ml}$ volumetric flask. We introduced $8 \mathrm{ml}$ of pyridine (w.ap: $7.88 \mathrm{~g}$ for density of 0.978 ) and $5 \mathrm{ml}$ of $\mathrm{CDCl}_{3}$ (7.5g for density of 1.5). This mixture was used for further preparation/dissolution. A solution of chromium (III) acetylacetonate and cyclohexanol was prepared in a solvent mixture of pyridine $(99.9 \%) / \mathrm{CDCl}_{3}(1.6 / 1 \mathrm{v} / \mathrm{v})$. Approximately $36 \mathrm{mg}$ of Chromium (II) and $40 \mathrm{mg}$ of cyclohexanol were weighed into a $10 \mathrm{ml}$ volumetric flask and $10 \mathrm{ml}$ of Pyridine $/ \mathrm{CDCl}_{3}$ mixture was added. This mixture was stirred in order to dissolve the Chromium. Cyclohexanol must be introduced with a high accuracy because any error could change extensively the quantification.

$400 \mu \mathrm{L}$ of Pyridine $/ \mathrm{CDCl}_{3}$ were added to the solid lignin. The solvent mixture was introduced into the $5 \mathrm{ml}$

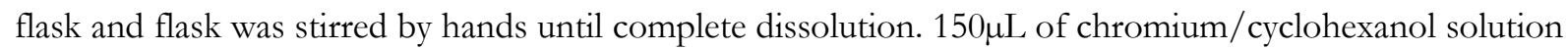
was introduced into the $5 \mathrm{ml}$ flask. The lignin solution was then mixed. Few minutes before the NMR experiments, $50 \mu \mathrm{L}$ of TMDP (2-chloro-4,4,5,5-tetramethyl-1,3,2-dioxaphospholane) was added to the $5 \mathrm{ml}$ flask. The flask was shaken (slowly) by hands for 1-2 minutes. The solution was transferred into a $5 \mathrm{~mm}$ NMR tube. Each sample was prepared before analysis to avoid chemical evolution during storage.

NMR measurements were performed on a Bruker $300 \mathrm{MHz}$ (31P resonance of $121.5 \mathrm{MHz}$ ). The following acquisition parameters were used: 200 scans, 25 s relaxation delay, $62 \mathrm{ppm}$ spectral width.

The quantification of $\mathrm{OH}$ groups has been done based on the internal standard (cyclohexanol 144.4ppm). The signal assignments are presented in Table S4. 
Table S4. Hydroxyl function assignments for ${ }^{31}$ P NMR

\begin{tabular}{|c|c|}
\hline Functions & $\begin{array}{c}\text { Integration range } \\
\text { (ppm) }\end{array}$ \\
\hline Aliphatic OH & $150-145$ \\
\hline Cyclohexanol & $144.6-144.2$ \\
\hline $\begin{array}{c}\text { Syringyl OH / C5 Condensed } \\
\text { structure }\end{array}$ & $144-140$ \\
\hline $\begin{array}{c}\text { Guaiacyl OH / p-hydroxy phenyl } \\
\text { OH (140 - 136 ppm) }\end{array}$ & $140-136$ \\
\hline Carboxylic acid & $136-132$ \\
\hline
\end{tabular}

We combined the Syringyl OH moieties with condensed 5-substitued phenolic units in order to prevent the over-estimation of S-units. For some spectra, Guaiacyl units was overlapped with free hydroxyl phenyl $\mathrm{OH}$ signal. Generally $\mathrm{G}$ units are combined with hydroxyl ( $\mathrm{H}$ units). In other words, the estimation of $\mathrm{S} / \mathrm{G} / \mathrm{H}$ ratio is not possible for these technical lignins by this ${ }^{31} \mathrm{P}$ NMR method.

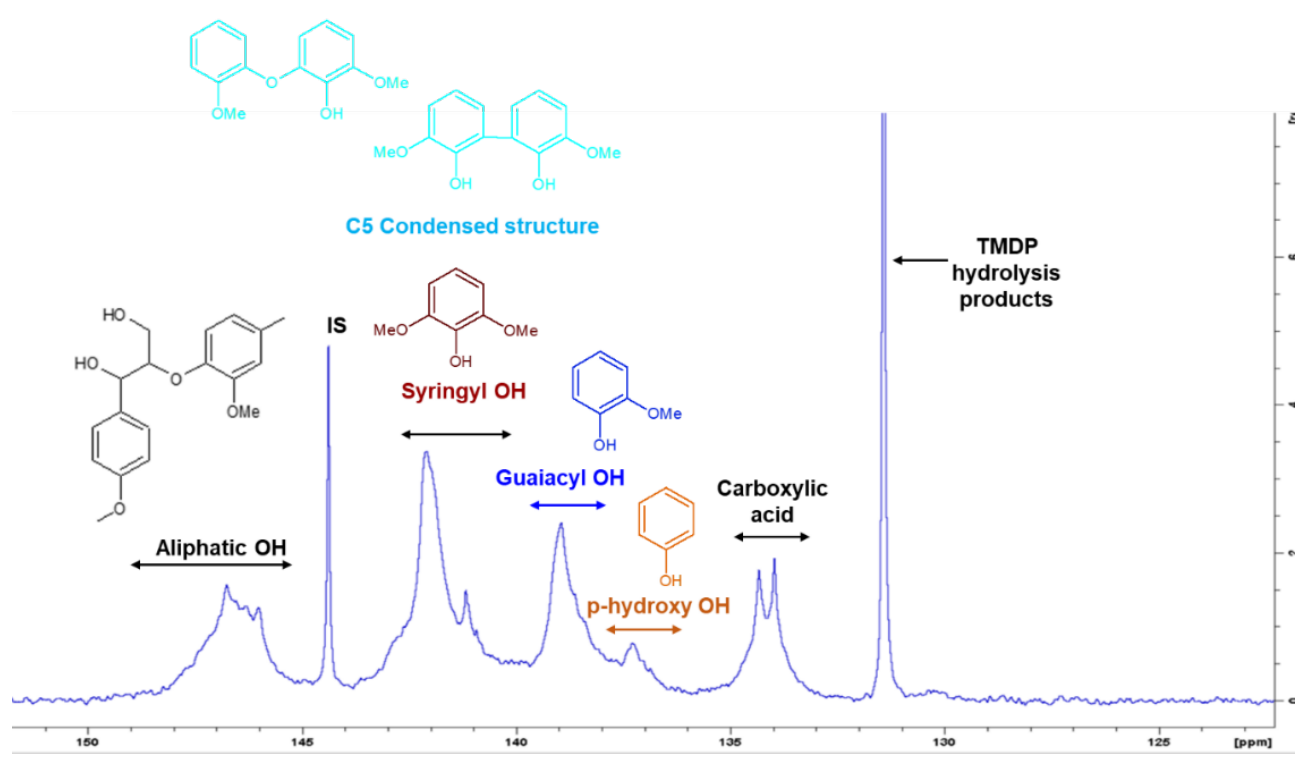

Figure S2. functional group analysis of Soda lignin by quantitative 31P NMR after phosphitylation

Observation: Soda lignin is composed by $\mathrm{S} / \mathrm{G} / \mathrm{H}$ free hydroxyl units. S signal overlapped signal for C5 substituted functions. So we did not attempt the estimation of $\mathrm{S}$ units. Peak at $141.15 \mathrm{ppm}$ could be lignins 5-5 condensation. 


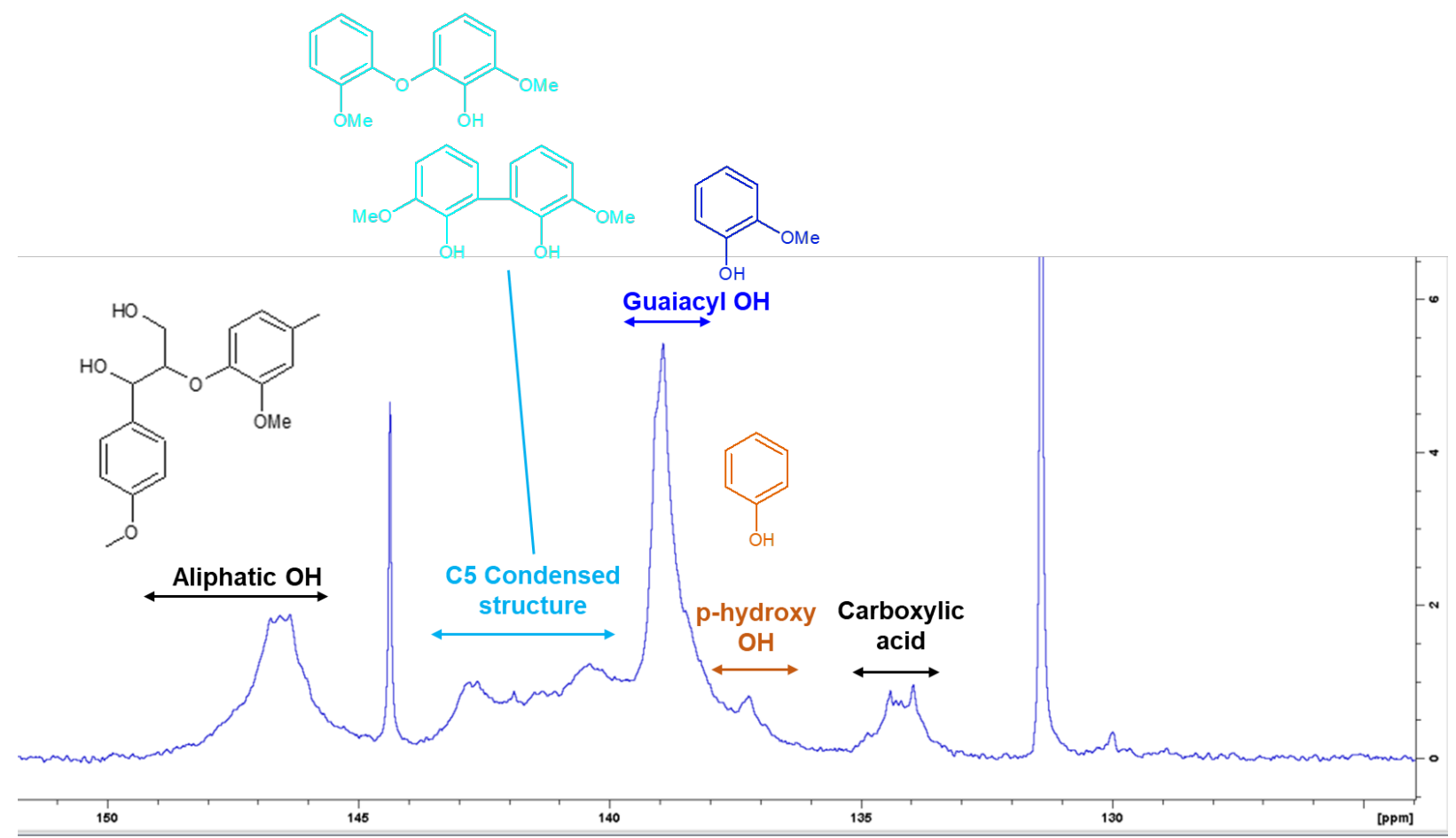

Figure S3. Kraft1 (Southern Pine) ${ }^{31}$ P NMR

Observation: No S units are detected (it is a Pine Kraft lignin).

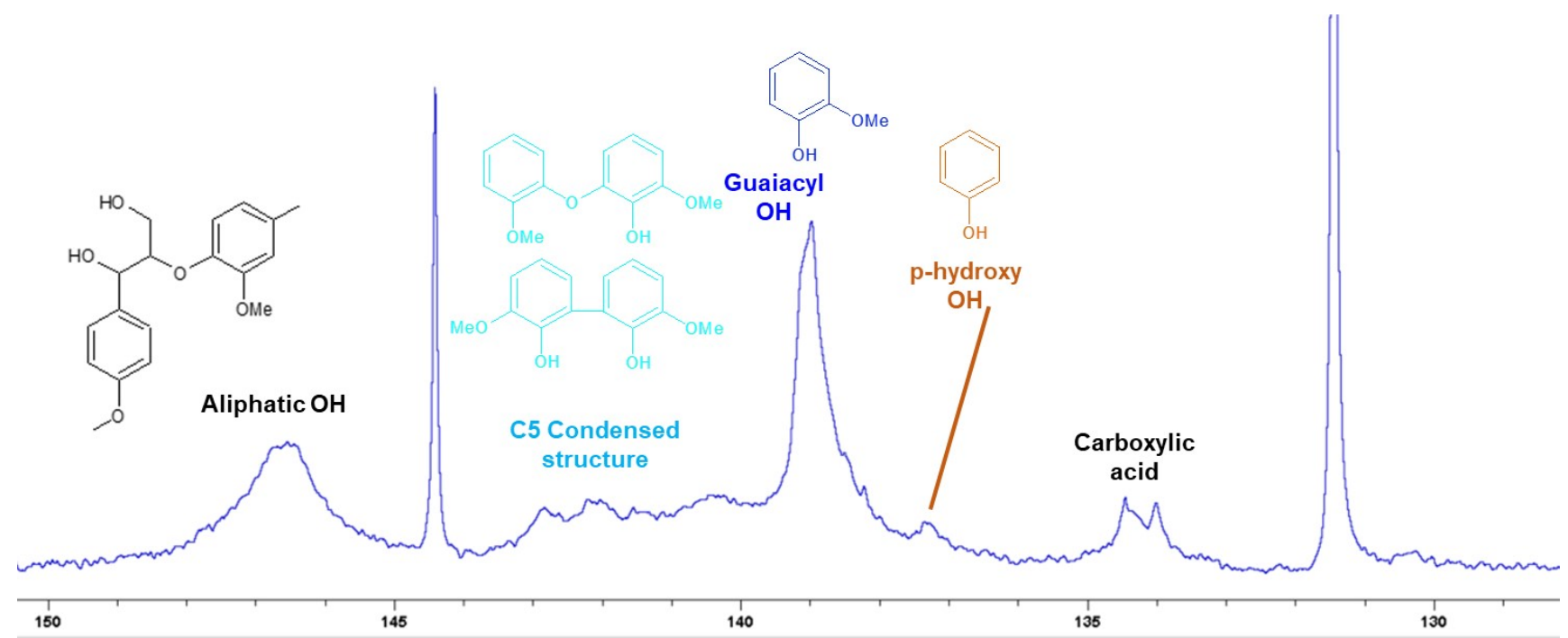

Figure S4. Kraft3 lignin ${ }^{31}$ P NMR

Observations : $G$ units seems to be the most important units. C5 condensed units are observed and small amount of $\mathrm{S}$ units are detected. 

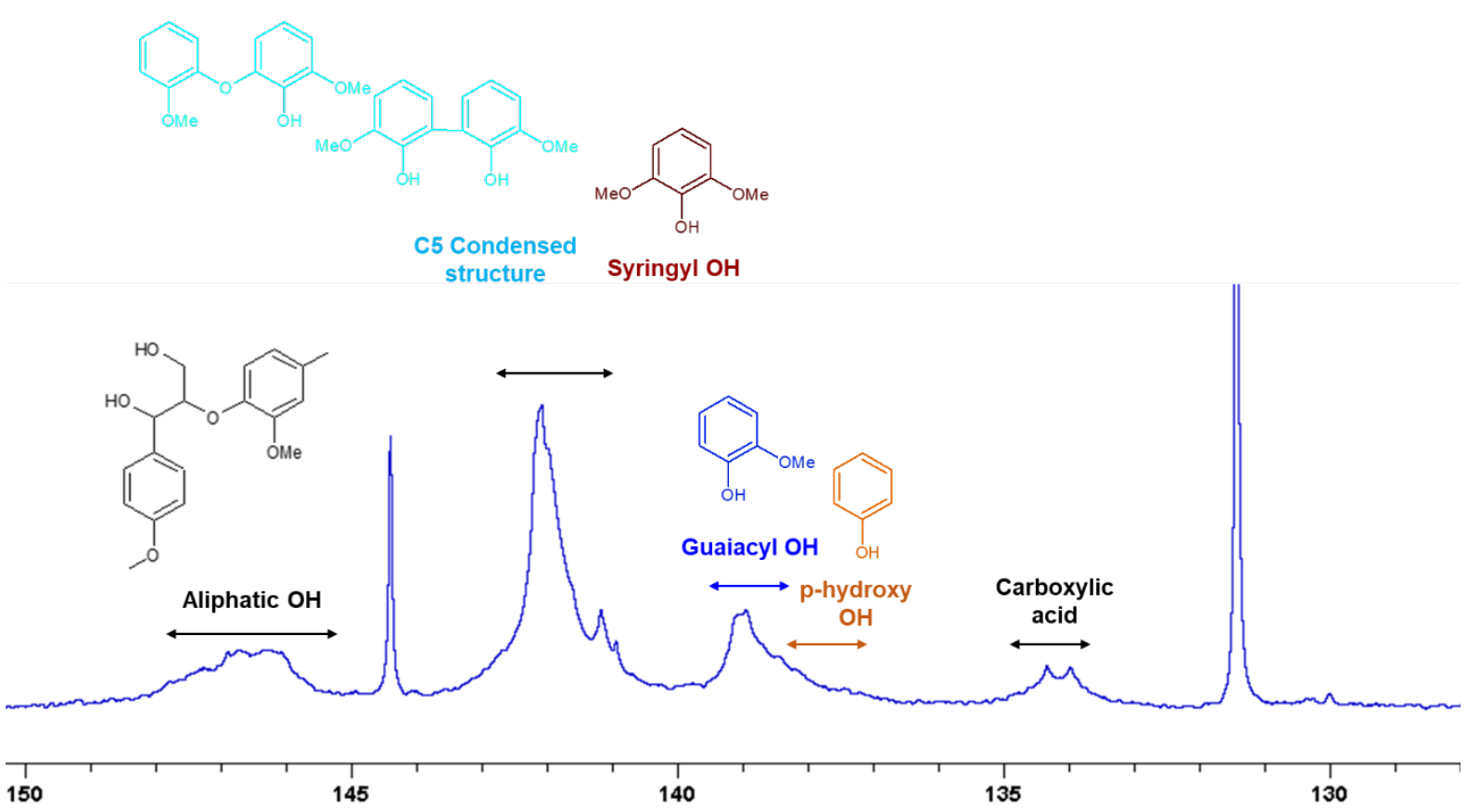

Figure S5. Kraft2 (Eucalyptus) from ${ }^{31} \mathrm{P}$ NMR

Observations: $\mathrm{G}$ and $\mathrm{H}$ free $\mathrm{OH}$ units content is lower than other Kraft. The $\mathrm{S}$ free units are the most important unit for this lignin.

For HSQC and ${ }^{13} \mathrm{C}$ NMR analysis, the lignins were dissolved in DMSO- $\mathrm{d}^{6}$ after overnight stirring (200 $\mathrm{mg} / 750 \mu \mathrm{L})$ and chemical shifts were referenced to the solvent signal $(2.50 / 39.5 \mathrm{ppm})$. The spectra were processed on Topspin 4.0.6 software $(\mathrm{LB}=10)$.

The 2D HSQC NMR spectra of lignin were acquired on a Bruker Bruker Avance III HD $300 \mathrm{MHz}$ spectrometer equipped with a $\mathrm{BBO}$ probe at $50^{\circ} \mathrm{C}$, in order to reduce viscosity, using the hsqcetgp pulse program. Matrices of 1024 data points for the ${ }^{1} \mathrm{H}$-dimension and 256 data points for the ${ }^{13} \mathrm{C}$-dimension were collected with a relaxation delay of $1.5 \mathrm{~s}$ and spectral widths from 9.5 to $-0.5 \mathrm{ppm}$ and from 180 to $0 \mathrm{ppm}$ for the ${ }^{1} \mathrm{H}$ and ${ }^{13} \mathrm{C}$ dimensions, respectively. Number of scans was 128.

HSQC semi-quantification of the main lignin linkages were performed using the correlation peak according to aromatic carbons. ${ }^{17} \mathrm{~S}_{2,6}(104.2 / 6.7)$ and $\mathrm{G}_{2}(110.2 / 6.9)$ have been used as reference and linkages concentration are expressed in table $\mathrm{S} 1$ as a number per 100 aromatic units $(\mathrm{S}+\mathrm{G})$. The integral value for each linkage were divided by the integral value for $S_{2,6} / 2+$ integral value for $G_{2}$.

${ }^{13} \mathrm{C}$ NMR spectra were acquired on the same Bruker Avance III HD $300 \mathrm{MHz}$ spectrometer $(75.46 \mathrm{MHz}$ for ${ }^{13} \mathrm{C}$ ). An inverse-gated decoupling pulse sequence (zgig pulse program) was used to avoid NOE effects. 10,000 scans were collected with a pulse delay of 12 s. 


\section{Characterization of catalysts}

\subsection{SEM/EDX}

SEM pictures with higher resolution than the ones presented in the main text are presented in figure S6.

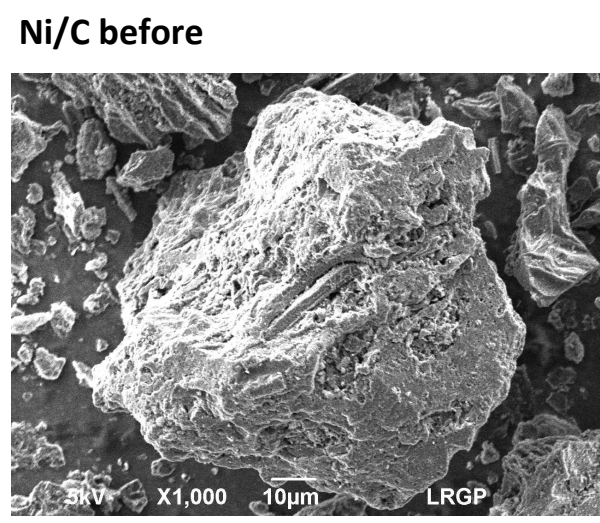

\section{$\mathrm{Ni} / \mathrm{C}$ after}

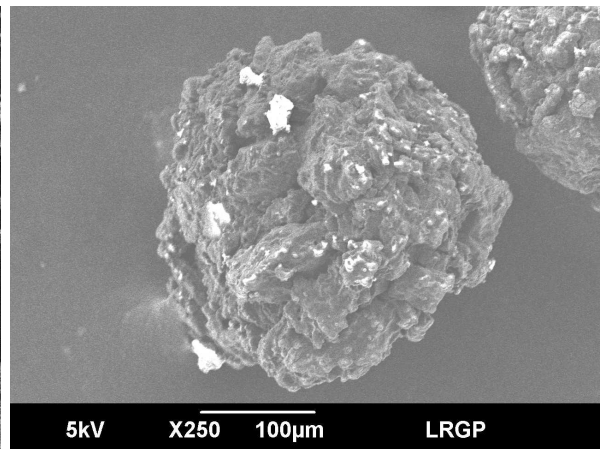

\section{$\mathrm{Pt} / \mathrm{C}$ before}

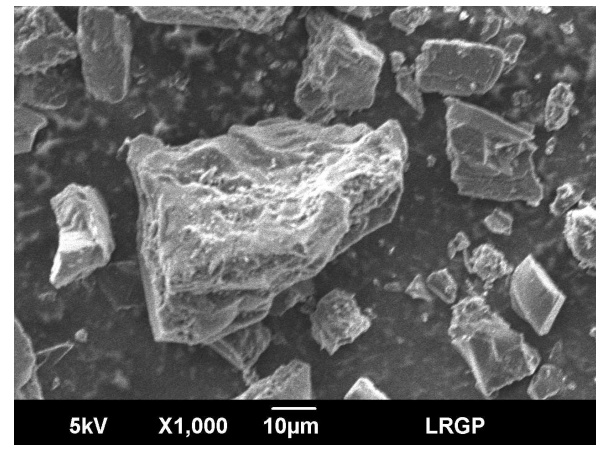

$\mathrm{Ru} / \mathrm{C}$ before

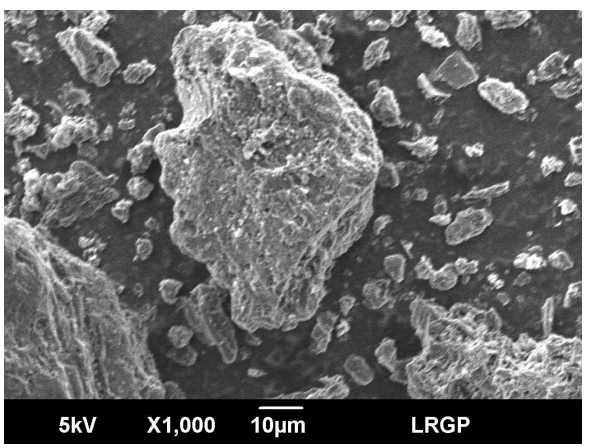

$\mathrm{Pt} / \mathrm{C}$ after

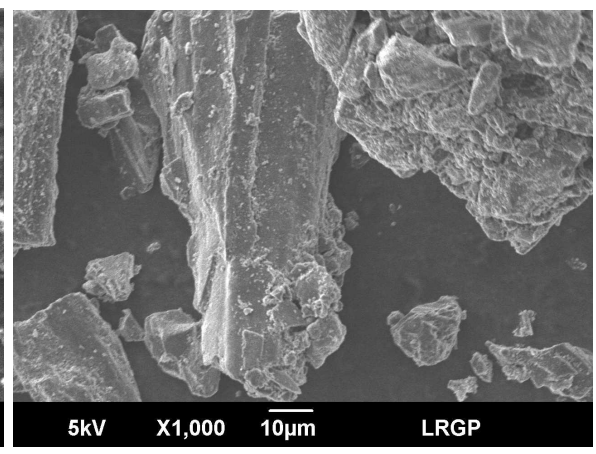

$\mathrm{Ru} / \mathrm{C}$ after

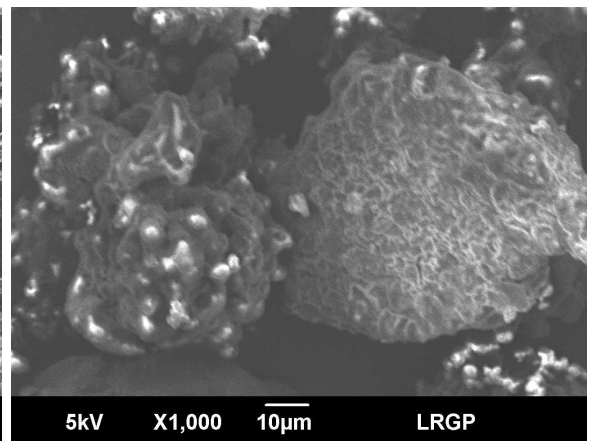

Figure S6. SEM pictures of the 3 catalysts before and after K3 depolymerization

EDX mappings and composition of the catalyst surface (at the $\mu \mathrm{m}$ scale) before and after reaction are presented in figure S7. 


\section{$\mathrm{Ni} / \mathrm{C}$ before reaction}

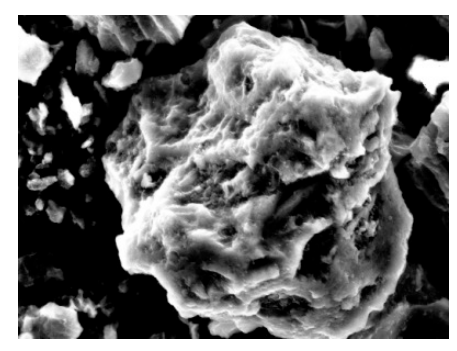

C

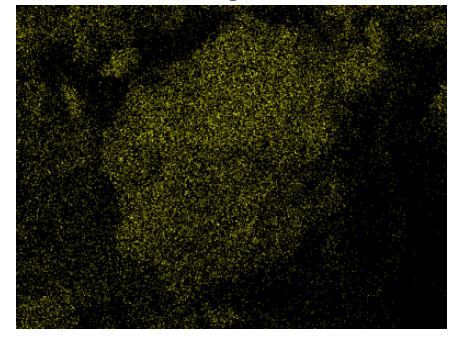

$\mathrm{Ni}$
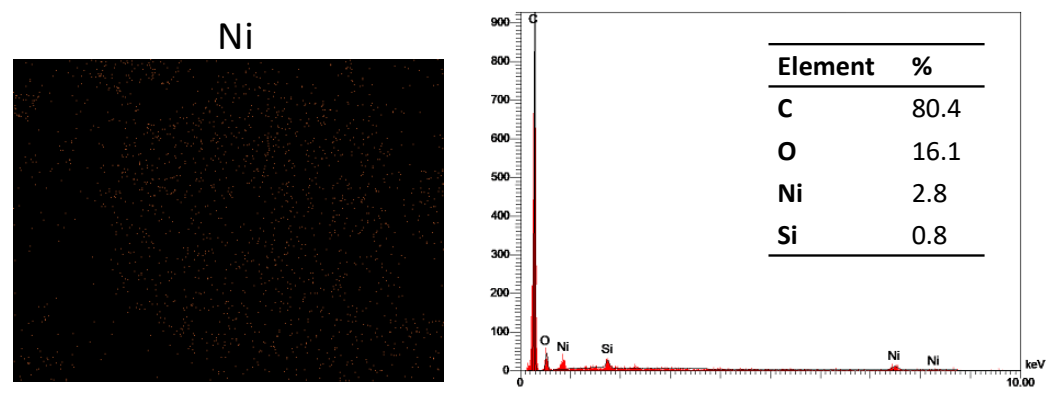

$\mathrm{Ni} / \mathrm{C}$ after reaction

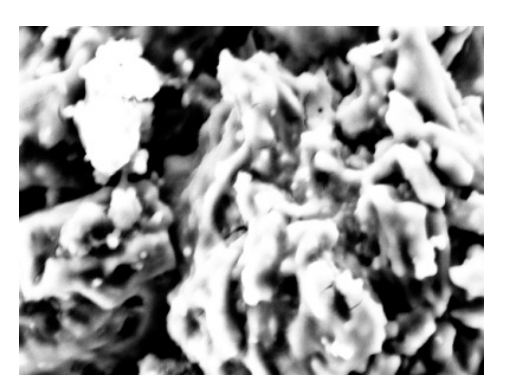

$\mathrm{Si}$

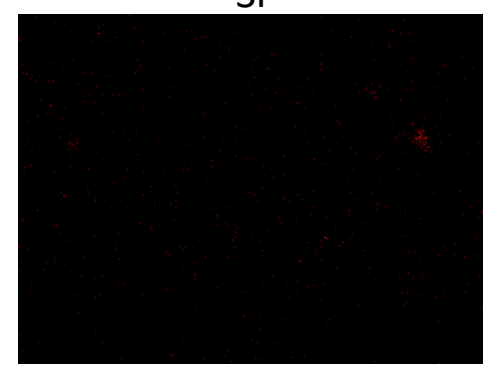

0

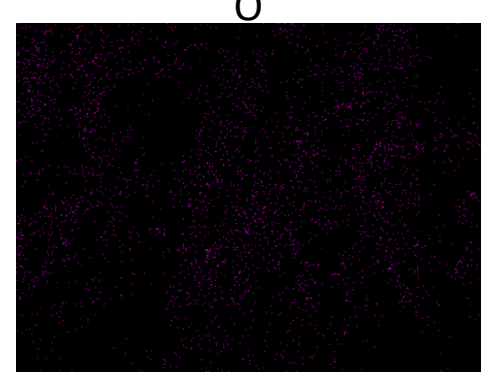

C

$\mathrm{Na}$
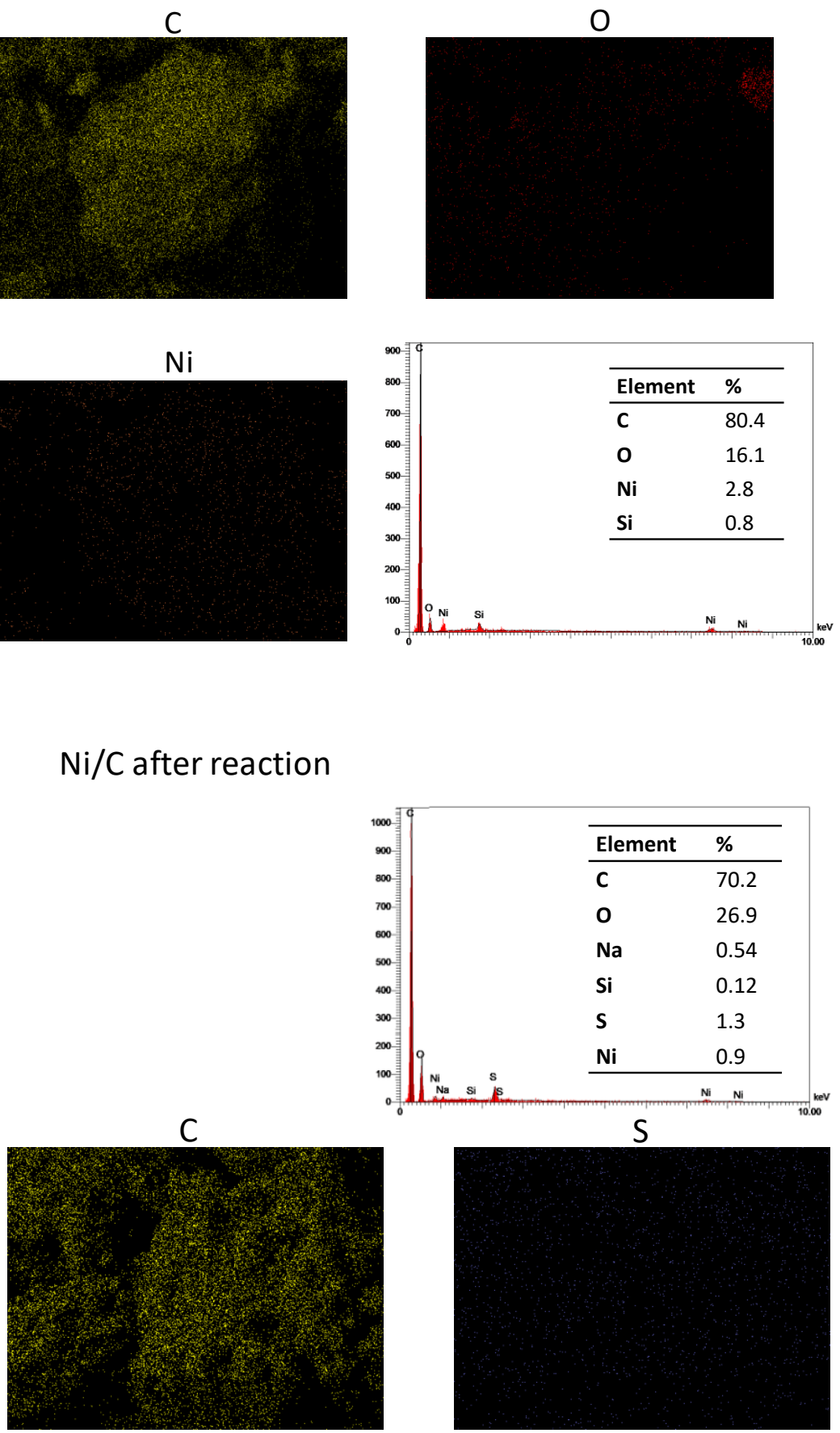

$\mathrm{Ni}$
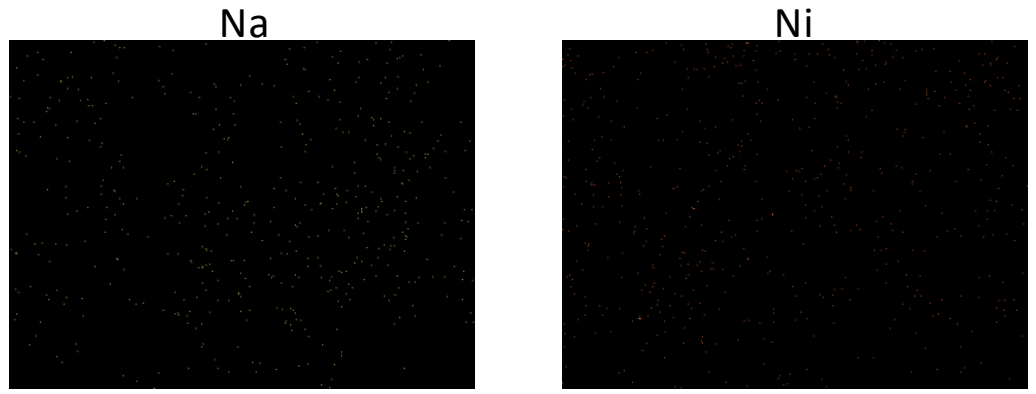
$\mathrm{Pt} / \mathrm{C}$ before reaction

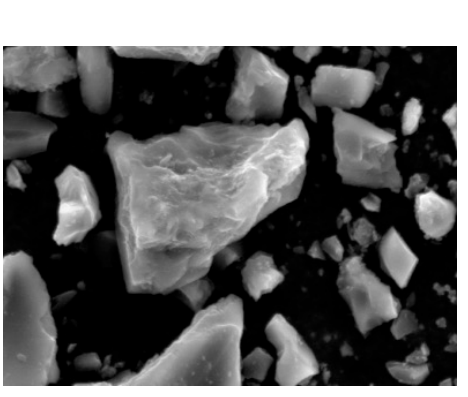

C

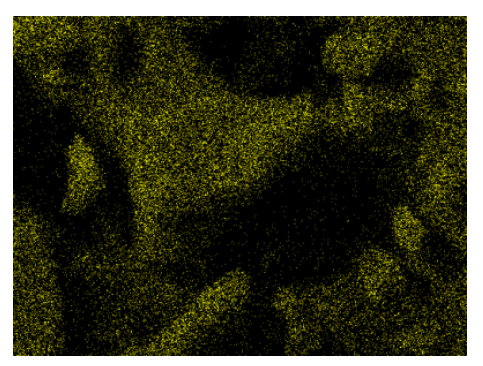

Pt
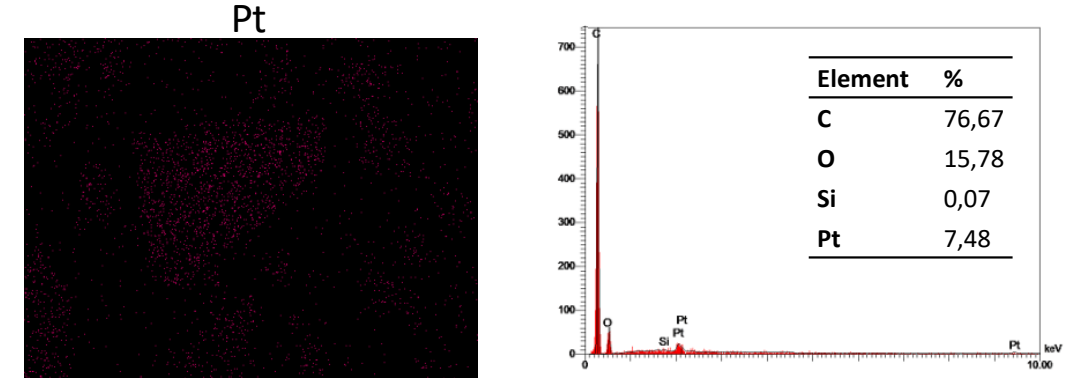

$\mathrm{Pt} / \mathrm{C}$ after reaction

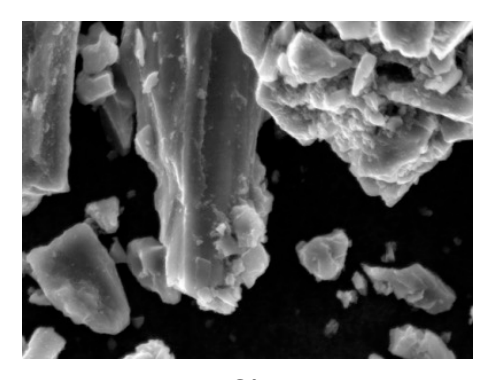

$\mathrm{Si}$

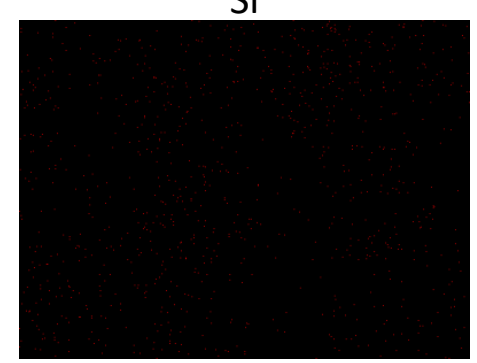

0

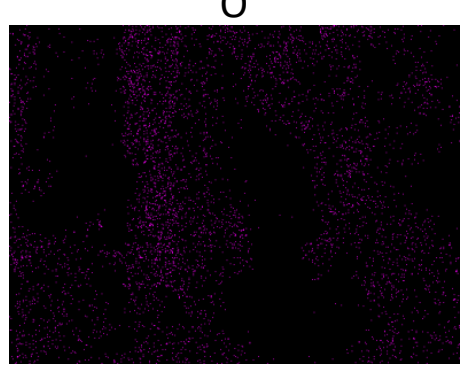

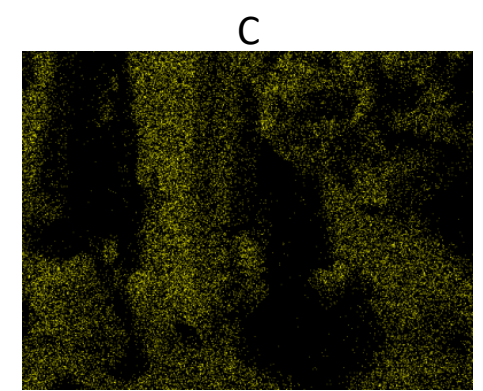

$\mathrm{Na}$

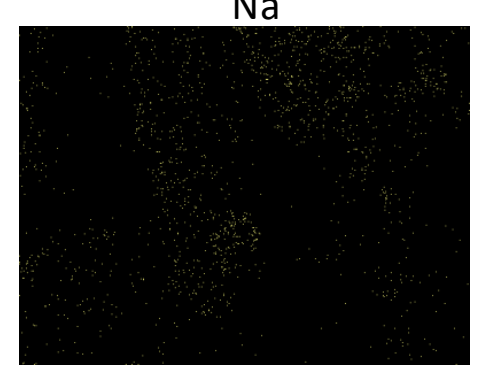

0
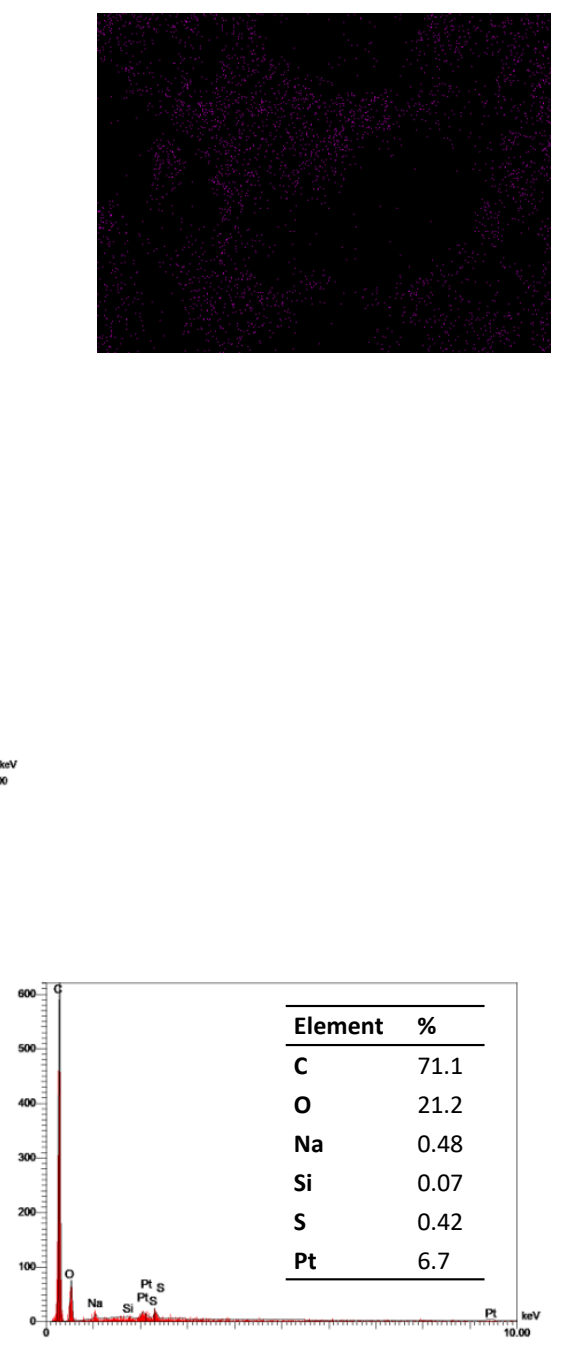

S

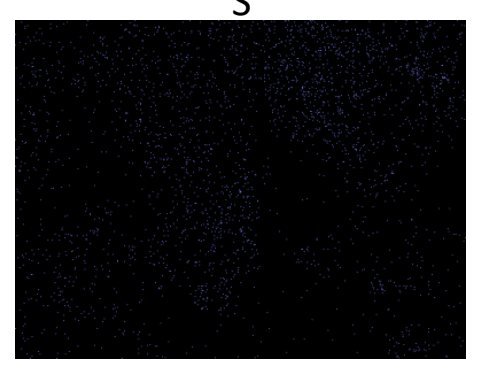

Pt 


\section{$\mathrm{Ru} / \mathrm{C}$ before reaction}

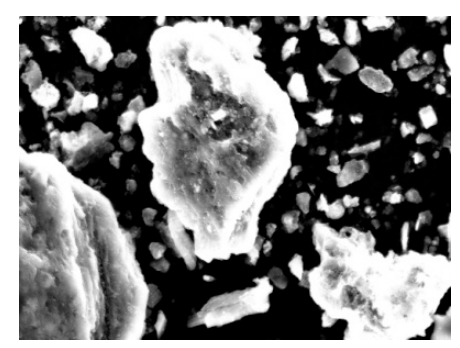

C

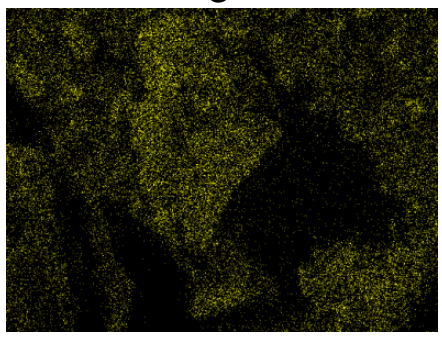

$\mathrm{Si}$

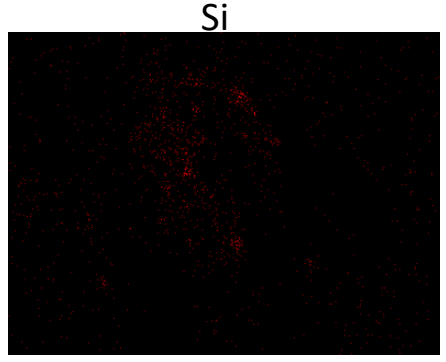

$\mathrm{Ru} / \mathrm{C}$ after reaction

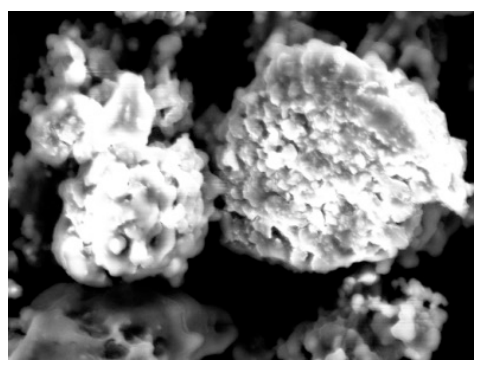

$\mathrm{Ru}$

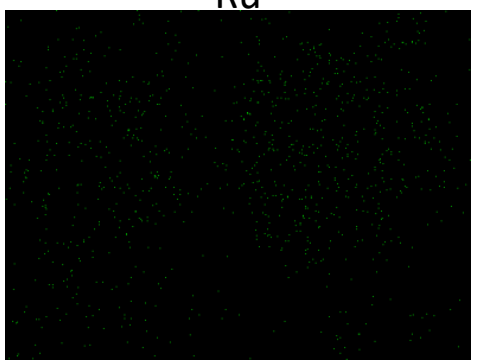

$\mathrm{Si}$

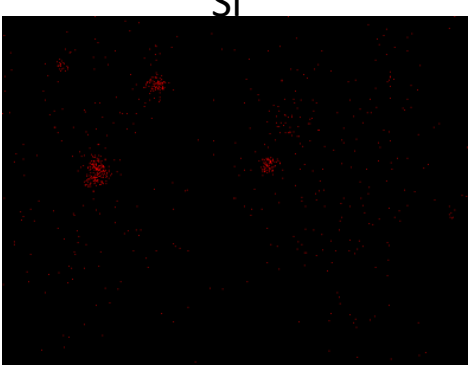

C

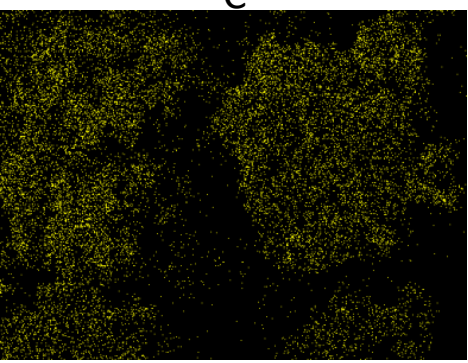

$\mathrm{Na}$

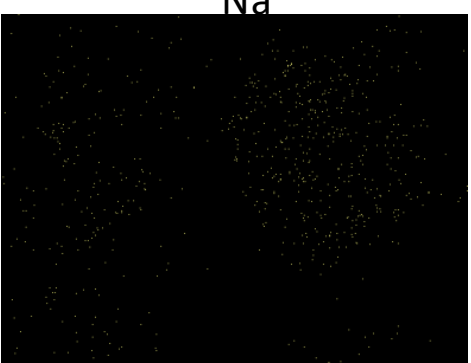

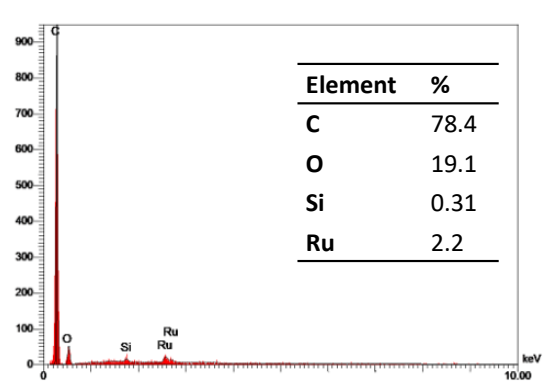

$\mathrm{Ru}$
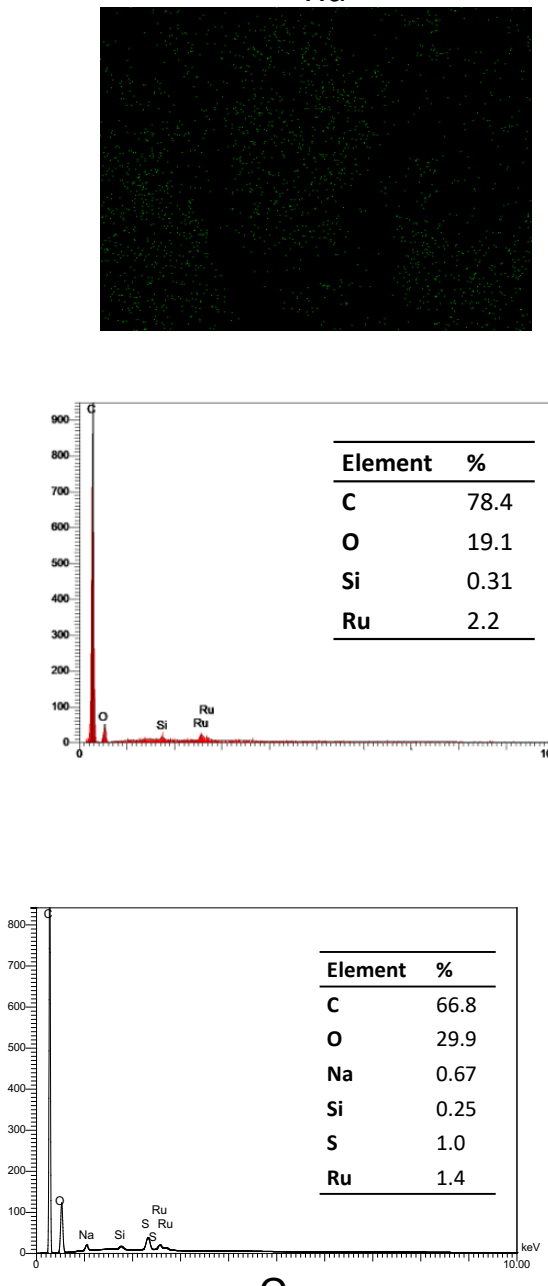

0

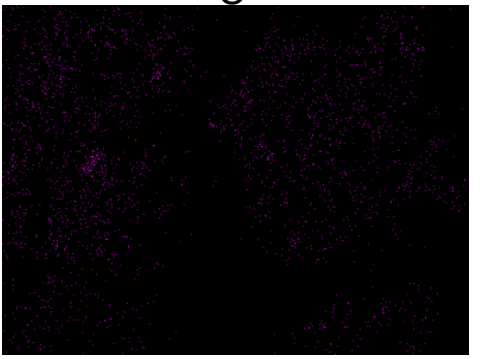

$\mathrm{S}$

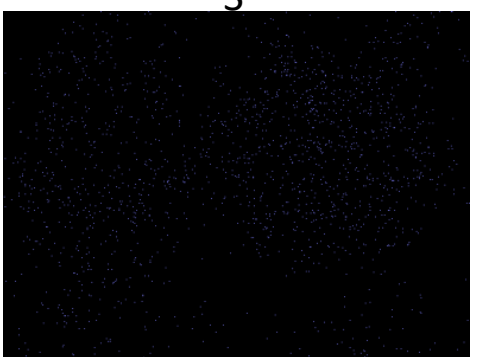

Figure S7. SEM-EDX of the 3 catalysts before and after K3 depolymerization highlighting the increase in $\mathrm{S}$ and $\mathrm{Na}$ on the surface of particles after depolymerization. $\mathrm{S}$ and $\mathrm{Na}$ are indicators of lignin-based deposit. 


\subsection{Particle size of metallic nanoparticles by TEM}

The particle size distribution of the nanoparticles of metals $(\mathrm{Ni}, \mathrm{Ru}, \mathrm{Pt})$ dispersed over the activated carbons analyzed by TEM is presented in figure S8.
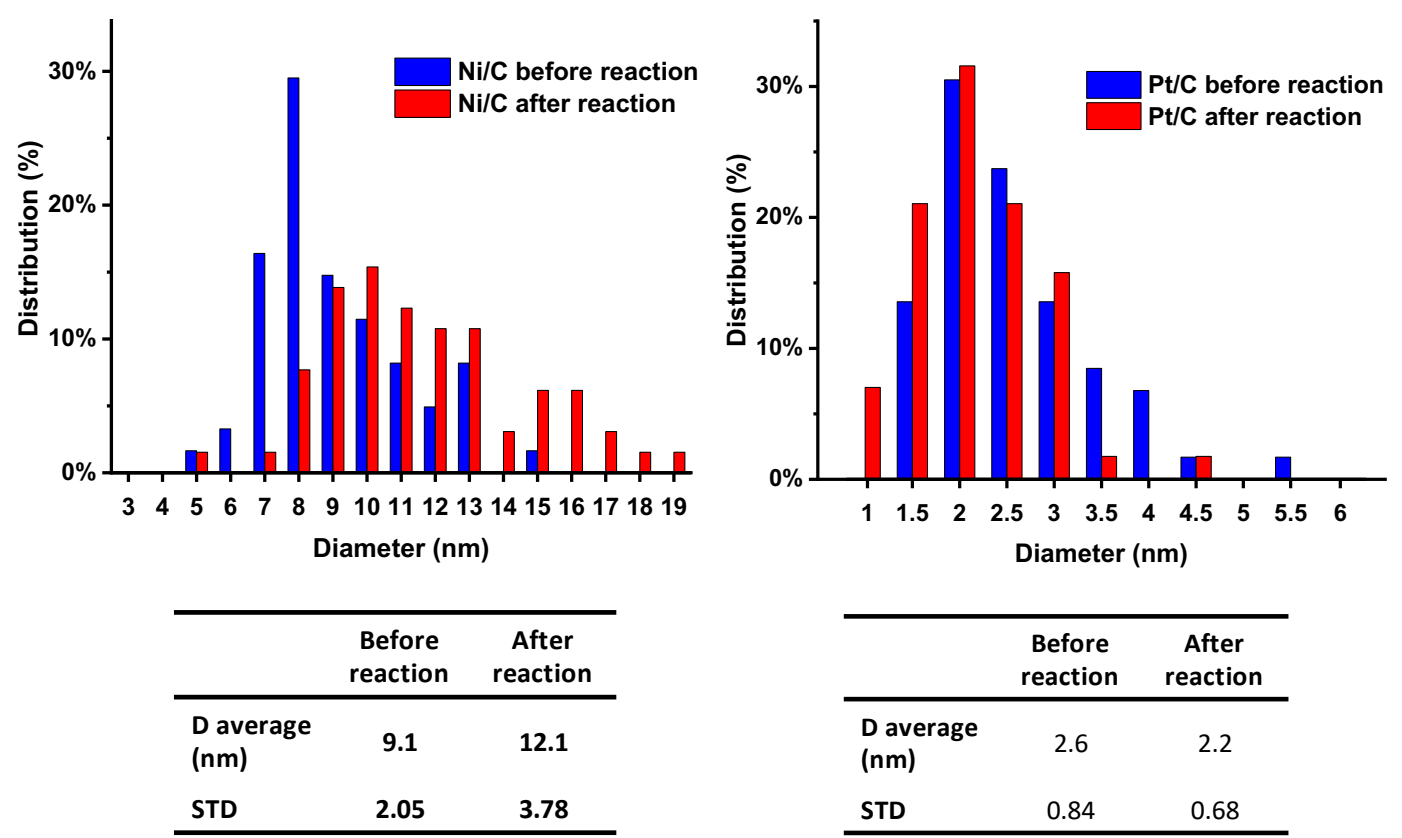

\begin{tabular}{lcc}
\hline & $\begin{array}{c}\text { Before } \\
\text { reaction }\end{array}$ & $\begin{array}{c}\text { After } \\
\text { reaction }\end{array}$ \\
\hline $\begin{array}{l}\text { D average } \\
(\mathrm{nm})\end{array}$ & 9.1 & 12.1 \\
STD & 2.05 & 3.78 \\
\hline
\end{tabular}

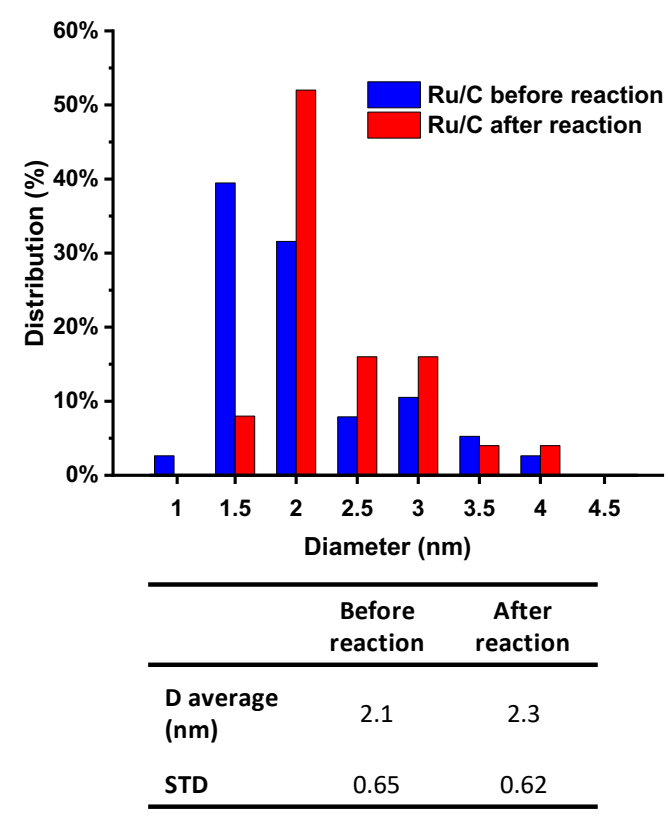

Figure S8. Size distribution (by TEM) of metal nanoparticles deposited over the activated carbons before and after $\mathrm{K} 3$ depolymerization $\left(4 \mathrm{~h}, 250^{\circ} \mathrm{C}\right.$, ethanol) 
4.3. XRD analysis of the catalysts

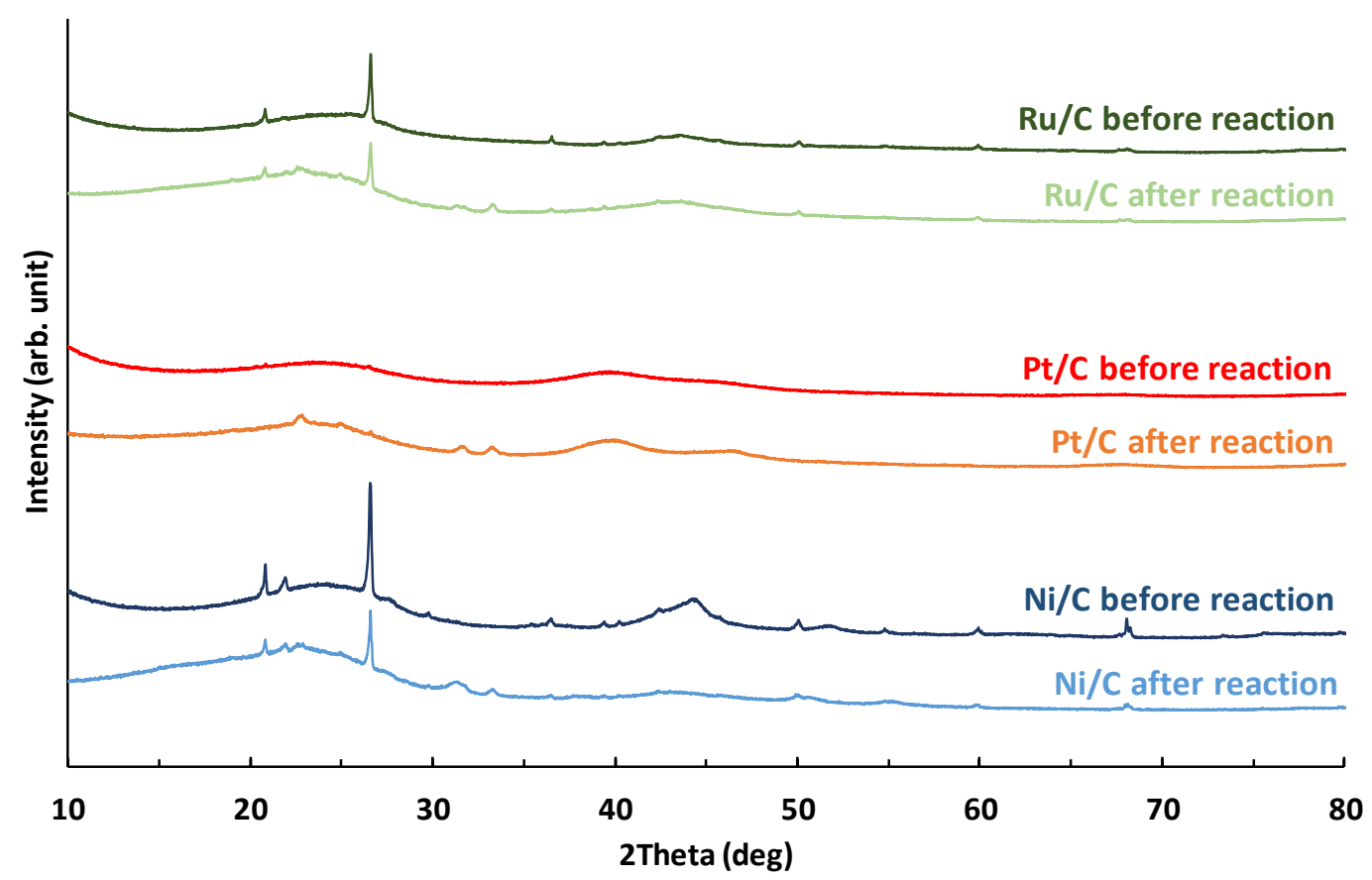

Figure S9. XRD analysis of the 3 catalysts before and after K3 lignin depolymerisation 


\section{4. $\mathbf{N}_{2}$ sorption and pores size distribution}
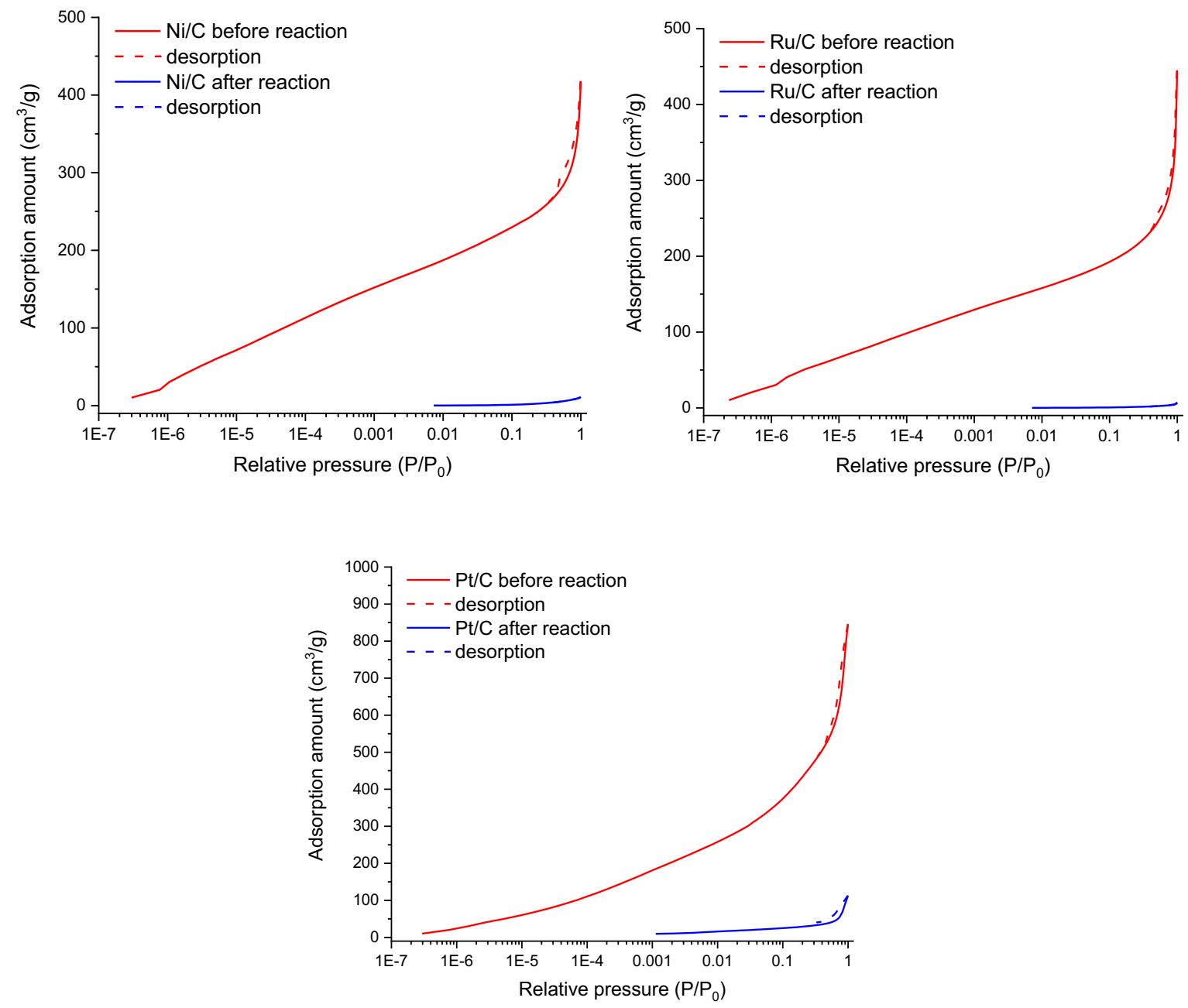

Figure S10. Sorption of $\mathrm{N}_{2}$ in the pristine and spent catalysts 

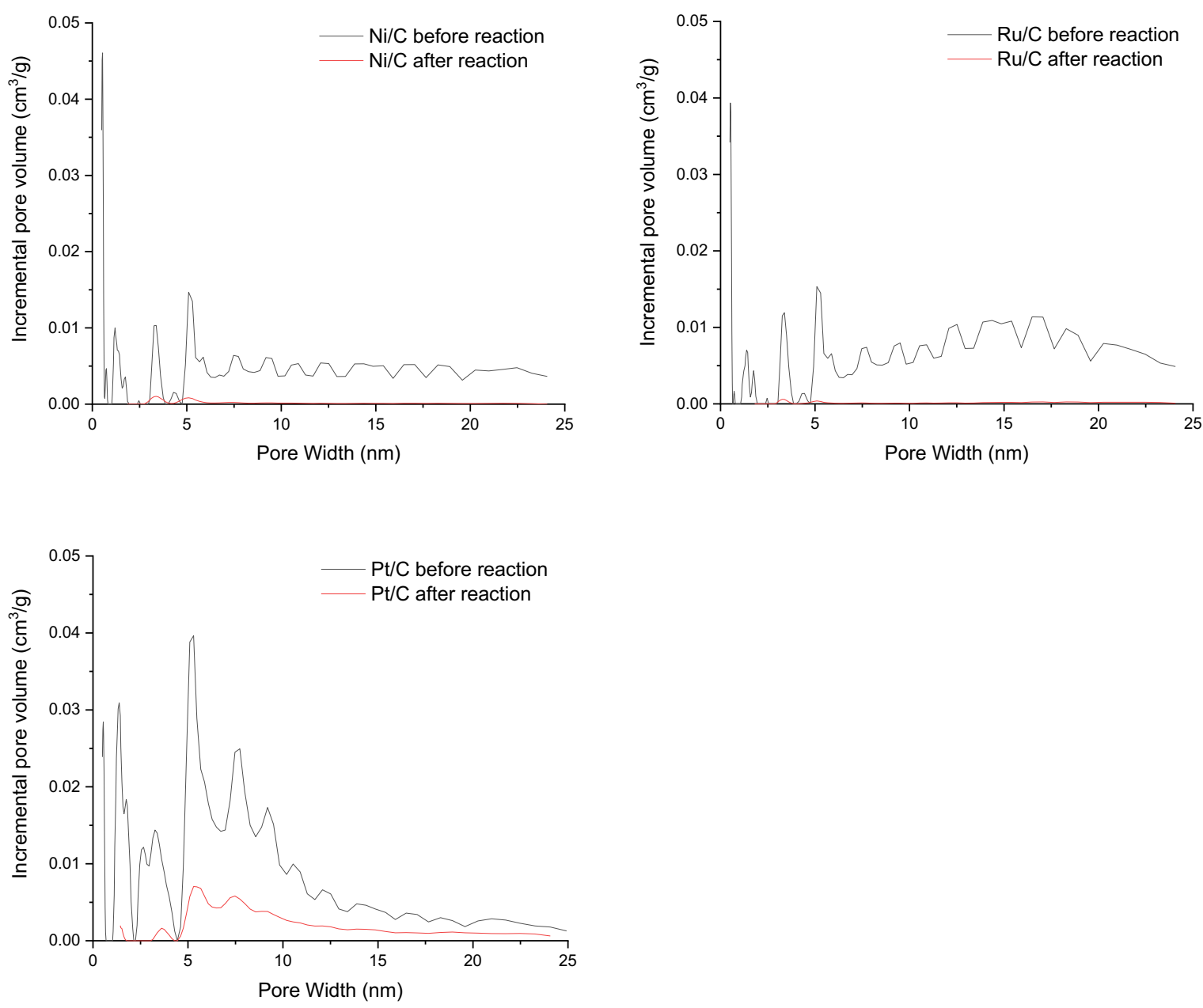

Figure S11. Distribution of pores size by NL-DFT

\section{Analysis of liquids}

\subsection{Methods}

\section{GC-MS analysis}

The samples were analyzed by an Agilent 7890 gas chromatograph combined to an Agilent 5975C MS (operated by electron impact at $70 \mathrm{eV}$ ) and an FID placed in parallel to the mass spectrometer. The samples were filtered $(0.45 \mu \mathrm{m}$ glass filters $)$ and no additional dilution was applied. The sample was injected $(1 \mu \mathrm{L})$ with a split ratio of 10 into an Agilent HP-5MS (5\% phenyl 95\% methyl siloxane) column. The oven was maintained at $50^{\circ} \mathrm{C}$ for $10 \mathrm{~min}$; then the temperature was increased with a first ramp of $5^{\circ} \mathrm{C} / \mathrm{min}$ to $120^{\circ} \mathrm{C}$, maintained for $10 \mathrm{~min}$ and then with a second ramp of $5^{\circ} \mathrm{C} / \mathrm{min}$ to $250^{\circ} \mathrm{C}$ and maintained for $18 \mathrm{~min}$. By comparison between the mass spectra and the NIST database, more than 40 compounds have been identified. The quantification was achieved by the FID detector based on the de Saint Laumer method as previously described in details. ${ }^{18}$ This method is able to predict the relative response factor of a compound on a FID based on its combustion enthalpy. 


\section{GPC-UV analysis}

The molecular weight distribution of lignin liquefaction products was determined by GPC using a Shimadzu Prominence HPLC system.

The samples, in ethanol from the reaction, were filtered ( $0.45 \mu \mathrm{m}$ glass filters) and then diluted in THF (by $1: 4 \mathrm{v} / \mathrm{v}$ ), the same solvent of the mobile phase. $20 \mu \mathrm{L}$ was injected. The stationary phase was composed of: 1) a Phenomenex Phenogel $5 \mu \mathrm{m}(7.8 \times 50 \mathrm{~mm})$ guard column, 2) a Shodex GPC KF-806L $10 \mu \mathrm{m}(8.0$ x $300 \mathrm{~mm}$ ) analytical column and 3) a Phenomenex Phenogel $5 \mu \mathrm{m} 100 \AA$ (7.8 x $300 \mathrm{~mm})$. The samples were separated at $35^{\circ} \mathrm{C}$ with a flow rate of $1 \mathrm{~mL} / \mathrm{min}$. The standards used for calibration were polystyrenes. We are aware that polystyrenes and lignin products present different hydrodynamic volumes for a same molecular weight but PS standards were used for sake of comparison with

the available literature on lignin liquefaction. The absorbance of the eluted products is presented at 254 $\mathrm{nm}$ (Shimadzu SPD-20A). Data were collected and analyzed with LabSolutions software.

\section{UV spectroscopy}

UV-visible absorption spectra were recorded on a UV-3600 double beam spectrophotometer (Shimadzu, Marne la Vallée, France). A spectral range from $200 \mathrm{~nm}$ to $500 \mathrm{~nm}$ and scan speed of $100 \mathrm{~nm}$ min-1 were selected with lamp change at $340 \mathrm{~nm}$. The fluorescence spectra were recorded on a Fluorolog FL3-222 spectrofluorometer (HORIBA Jobin Yvon, Longjumeau, France) equipped with a $450 \mathrm{~W}$ Xenon lamp, and a UV-Visible photomultiplier R928 (HAMAMATSU Japan). All spectra were measured in a fourfaced quartz cell. Fluorescence spectra were obtained with right angle detector position for both emission and synchronous acquisitions. Emission acquisition was performed with excitation wavelength of $275 \mathrm{~nm}$ and a slit of $2 \mathrm{~nm}$ for a spectral range of $280 \mathrm{~nm}$ to $530 \mathrm{~nm}$. Synchronous acquisition was performed with a constant wavelength offset of $20 \mathrm{~nm}$ in the spectral range from $250 \mathrm{~nm}$ to $500 \mathrm{~nm}$. The $20 \mathrm{~nm}$ offset has been selected based on our previous work ${ }^{19}$. The samples were diluted in ethanol until the absorption wavelength at $275 \mathrm{~nm}$ was approximately 0.2 , in order to avoid self-absorption effects. For this purpose, the solutions sampled from lignin liquefaction ( $10 \mathrm{~g}$ of lignin in $200 \mathrm{~mL}$ ethanol, $50 \mathrm{~g}$ lignin equivalent $/ \mathrm{L}$ ) were diluted 1000 or 2000 times in ethanol. Therefore, the concentration of analyzed solutions is in the range of $25-50 \mathrm{mg}$ lignin equivalent/L ethanol for UV analysis. All the synchronous fluorescence spectra are presented at the same absorbance. The whole procedure (including dilution, scan acquisition and treatment of data) lasts only about 15 minutes.

\subsection{Results of liquid analysis}

\subsubsection{GPC analysis of liquids}

Table S5. GPC analysis of the liquids after $4 \mathrm{~h}$ of reaction

\begin{tabular}{|c|c|c|c|}
\hline & Mn (Da) & Mw (Da) & $\begin{array}{c}\text { PD } \\
(\mathrm{Mw} / \mathrm{Mn})\end{array}$ \\
\hline K3 1\% Ru & 368 & 720 & 1,96 \\
\hline $\mathrm{K} 31 \% \mathrm{Ni}$ & 389 & 826 & 2,12 \\
\hline K3 1\% Pt & 409 & 865 & 2,11 \\
\hline $\mathrm{K} 11 \% \mathrm{Ni}$ & 394 & 850 & 2,16 \\
\hline $\mathrm{K} 21 \% \mathrm{Ni}$ & 396 & 829 & 2,09 \\
\hline Soda $1 \% \mathrm{Ni}$ & 380 & 935 & 2,46 \\
\hline
\end{tabular}



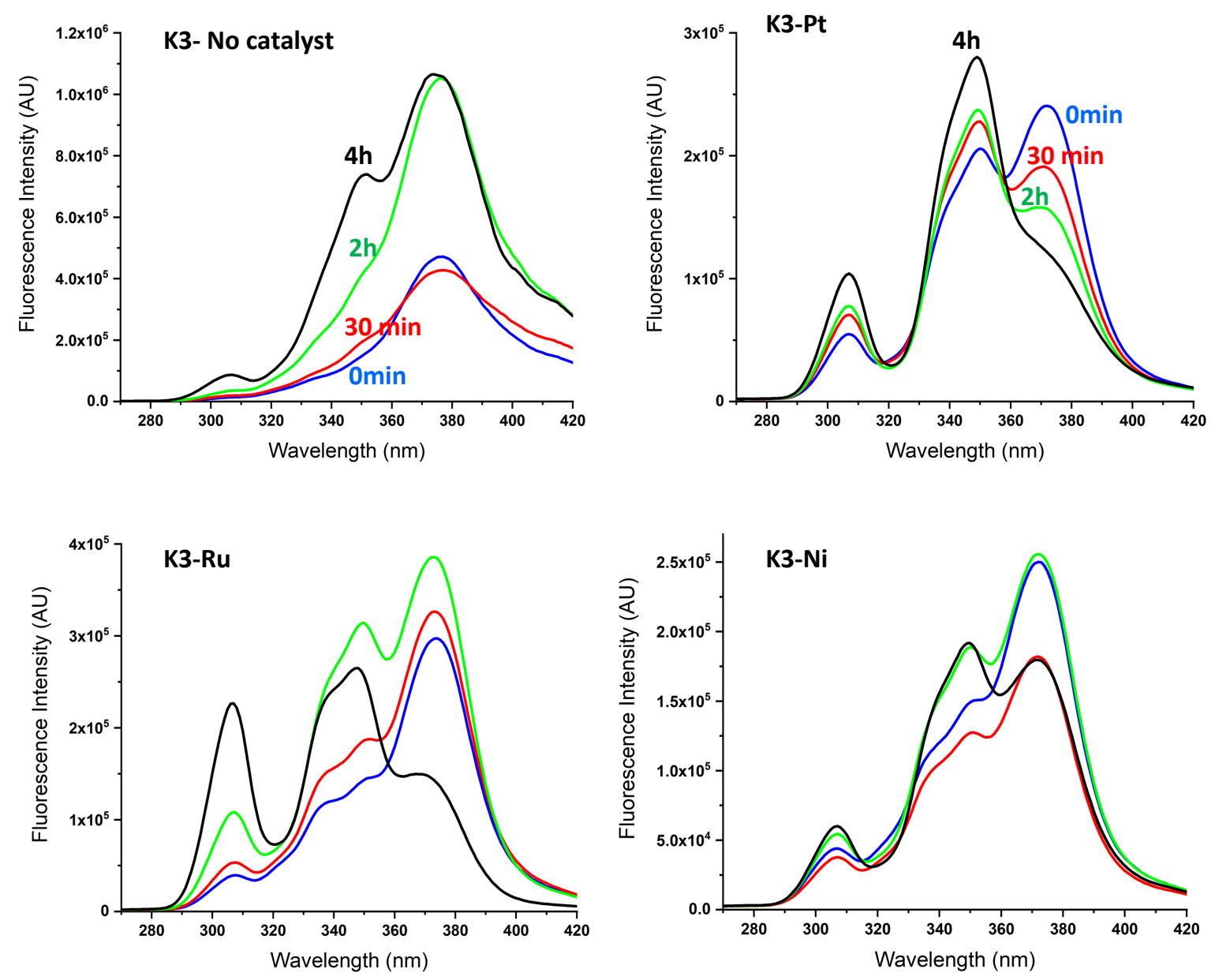

Figure S12. UV fluorescence for K3 lignin as a function of the depolymerization time and of catalysts $\left(250^{\circ} \mathrm{C}\right.$, ethanol $)$

2 exemples of deconvolution are provided. 4 peaks were used to deconvolute the UV fluorescence signal in order to better represent the complexity of the molecular pool in the liquids.
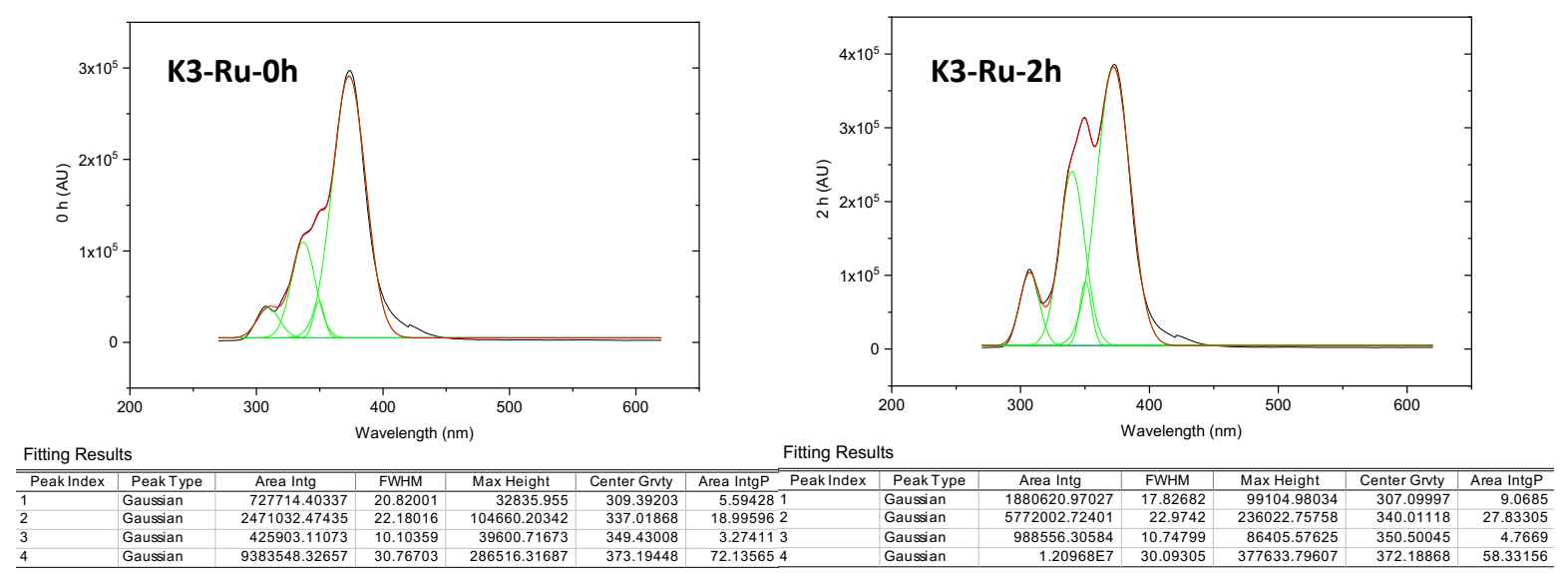

Figure S13. Examples of deconvolution of the UV fluorescence spectra 

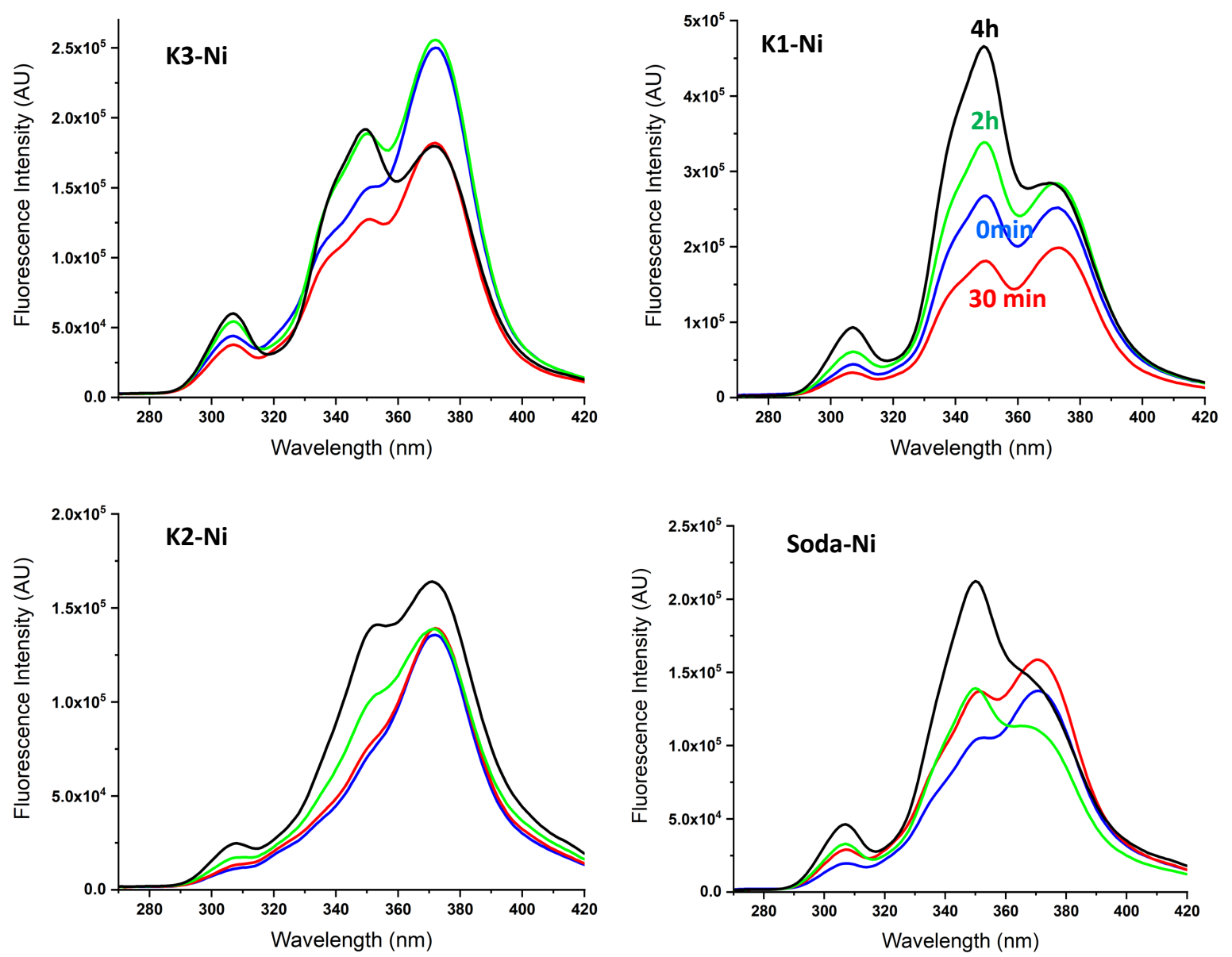

Figure S14. UV fluorescence for the 4 lignins with $\mathrm{Ni} / \mathrm{C}$ catalyst as a function of the depolymerization time $\left(250^{\circ} \mathrm{C}\right.$, ethanol $)$

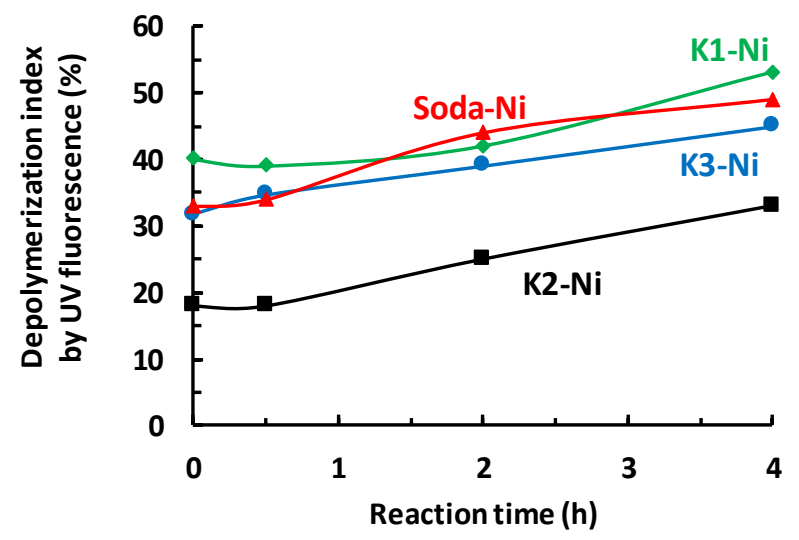

Figure S15. Evolution of the depolymerization index from UV fluorescence for the 4 lignins and as a function of reaction time (liquids sampled at $250^{\circ} \mathrm{C}, \mathrm{Ni} / \mathrm{C}$ ) 
5.2.3. Monomers by GC/MS-FID (wt. \% of lignin mass)

Table S6. Mass yields in main monomers (wt.\%) for all conditions

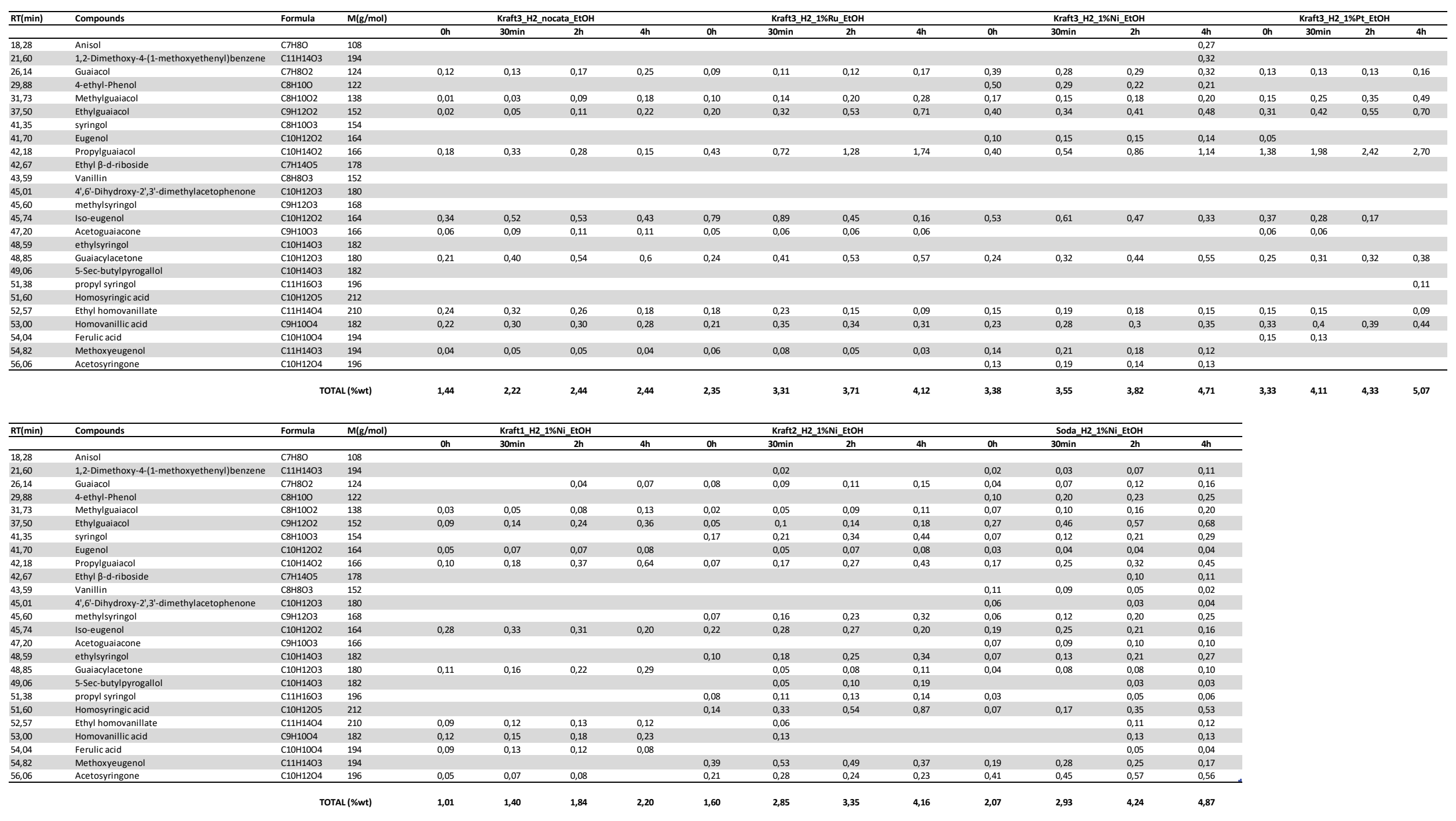

Page S20/S22 


\section{References cited in this supporting information}

(1) Jongerius, A. L.; Bruijnincx, P. C. A.; Weckhuysen, B. M. Liquid-Phase Reforming and Hydrodeoxygenation as a Two-Step Route to Aromatics from Lignin. Green Chem. 2013, 15 (11), 3049-3056. https://doi.org/10.1039/C3GC41150H.

(2) Huang, X.; Korányi, T. I.; Boot, M. D.; Hensen, E. J. M. Catalytic Depolymerization of Lignin in Supercritical Ethanol. ChemSusChem 2014, 7 (8), 2276-2288. https://doi.org/10.1002/cssc.201402094.

(3) Huang, X.; Korányi, T. I.; Boot, M. D.; Hensen, E. J. M. Ethanol as Capping Agent and Formaldehyde Scavenger for Efficient Depolymerization of Lignin to Aromatics. Green Chem. 2015, 17 (11), 4941-4950. https://doi.org/10.1039/C5GC01120E.

(4) Zhou, M.; Sharma, B. K.; Liu, P.; Ye, J.; Xu, J.; Jiang, J.-C. Catalytic in Situ Hydrogenolysis of Lignin in Supercritical Ethanol: Effect of Phenol, Catalysts, and Reaction Temperature. ACS Sustainable Chem. Eng. 2018, 6 (5), 6867-6875. https://doi.org/10.1021/acssuschemeng.8b00701.

(5) Limarta, S. O.; Ha, J.-M.; Park, Y.-K.; Lee, H.; Suh, D. J.; Jae, J. Efficient Depolymerization of Lignin in Supercritical Ethanol by a Combination of Metal and Base Catalysts. Journal of Industrial and Engineering Chemistry 2018, 57, 45-54. https://doi.org/10.1016/j.jiec.2017.08.006.

(6) Kim, J.-Y.; Park, J.; Kim, U.-J.; Choi, J. W. Conversion of Lignin to Phenol-Rich Oil Fraction under Supercritical Alcohols in the Presence of Metal Catalysts. Energy \& Fuels 2015, 29 (8), 5154-5163. https://doi.org/10.1021/acs.energyfuels.5b01055.

(7) Yang, J.; Zhao, L.; Liu, S.; Wang, Y.; Dai, L. High-Quality Bio-Oil from One-Pot Catalytic Hydrocracking of Kraft Lignin over Supported Noble Metal Catalysts in Isopropanol System. Bioresource Technology 2016, 212, 302-310. https://doi.org/10.1016/j.biortech.2016.04.029.

(8) Kong, L.; Liu, C.; Gao, J.; Wang, Y.; Dai, L. Efficient and Controllable Alcoholysis of Kraft Lignin Catalyzed by Porous Zeolite-Supported Nickel-Copper Catalyst. Bioresource Technology 2019, 276, 310 317. https://doi.org/10.1016/j.biortech.2019.01.015.

(9) Wang, S.; Li, W.-X.; Yang, Y.-Q.; Chen, X.; Ma, J.; Chen, C.; Xiao, L.-P.; Sun, R.-C. Unlocking Structure-Reactivity Relationships for Catalytic Hydrogenolysis of Lignin into Phenolic Monomers. ChemSusChem 2020, 13 (17), 4548-4556. https://doi.org/10.1002/cssc.202000785.

(10) Cheng, C.; Li, P.; Yu, W.; Shen, D.; Jiang, X.; Gu, S. Nonprecious Metal/Bimetallic Catalytic Hydrogenolysis of Lignin in a Mixed-Solvent System. ACS Sustainable Chem. Eng. 2020, 8 (43), 16217-16228. https://doi.org/10.1021/acssuschemeng.0c05362.

(11) Limarta, S. O.; Kim, H.; Ha, J.-M.; Park, Y.-K.; Jae, J. High-Quality and Phenolic Monomer-Rich Bio-Oil Production from Lignin in Supercritical Ethanol over Synergistic $\mathrm{Ru}$ and $\mathrm{Mg}$ - $\mathrm{Zr}$-Oxide Catalysts. Chemical Engineering Journal 2020, 396, 125175. https://doi.org/10.1016/j.cej.2020.125175.

(12) Zinovyev, G.; Sulaeva, I.; Podzimek, S.; Rössner, D.; Kilpeläinen, I.; Sumerskii, I.; Rosenau, T.; Potthast, A. Getting Closer to Absolute Molar Masses of Technical Lignins. ChemSusChem 2018, 11 (18), 3259-3268. https://doi.org/10.1002/cssc.201801177.

(13) Huang, X.; Atay, C.; Korányi, T. I.; Boot, M. D.; Hensen, E. J. M. Role of Cu-Mg-Al Mixed Oxide Catalysts in Lignin Depolymerization in Supercritical Ethanol. ACS Catalysis 2015, 5 (12), 73597370. https://doi.org/10.1021/acscatal.5b02230.

(14) Huang, X.; Atay, C.; Zhu, J.; Palstra, S. W. L.; Korányi, T. I.; Boot, M. D.; Hensen, E. J. M. Catalytic Depolymerization of Lignin and Woody Biomass in Supercritical Ethanol: Influence of Reaction Temperature and Feedstock. ACS Sustainable Chemistry \& Engineering 2017, 5 (11), 10864-10874. https://doi.org/10.1021/acssuschemeng.7b02790.

(15) Bayerbach, R.; Nguyen, V. D.; Schurr, U.; Meier, D. Characterization of the Water-Insoluble Fraction from Fast Pyrolysis Liquids (Pyrolytic Lignin). Journal of Analytical and Applied Pyrolysis 2006, 77 (2), 95-101. https://doi.org/10.1016/j.jaap.2006.02.002.

(16) Kim, J.-Y.; Park, J.; Hwang, H.; Kim, J. K.; Song, I. K.; Choi, J. W. Catalytic Depolymerization of Lignin Macromolecule to Alkylated Phenols over Various Metal Catalysts in Supercritical TertButanol. Journal of Analytical and Applied Pyrolysis 2015, 113, 99-106. https://doi.org/10.1016/j.jaap.2014.11.011.

(17) Constant, S.; Wienk, H. L. J.; Frissen, A. E.; Peinder, P. de; Boelens, R.; van Es, D. S.; Grisel, R. J. H.; Weckhuysen, B. M.; Huijgen, W. J. J.; Gosselink, R. J. A.; Bruijnincx, P. C. A. New Insights into 
the Structure and Composition of Technical Lignins: A Comparative Characterisation Study. Green Chemistry 2016, 18 (9), 2651-2665. https://doi.org/10.1039/C5GC03043A.

(18) Olcese, R.; Carré, V.; Aubriet, F.; Dufour, A. Selectivity of Bio-Oils Catalytic Hydrotreatment Assessed by Petroleomic and GC*GC/MS-FID Analysis. Energy Fuels 2013, 27 (4), 2135-2145. https://doi.org/10.1021/ef302145g.

(19) Bartolomei, E.; Le Brech, Y.; Dufour, A.; Carre, V.; Aubriet, F.; Terrell, E.; Garcia-Perez, M.; Arnoux, P. Lignin Depolymerization: A Comparison of Methods to Analyze Monomers and Oligomers. ChemSusChem 2020, 13 (17), 4633-4648. https://doi.org/10.1002/cssc.202001126. 